\title{
Eindeloos Groenten
}

'Voedsel moet voedsel blijven' - verwaarding resten uit groenteteelt en verwerking

H.M. Vollebregt

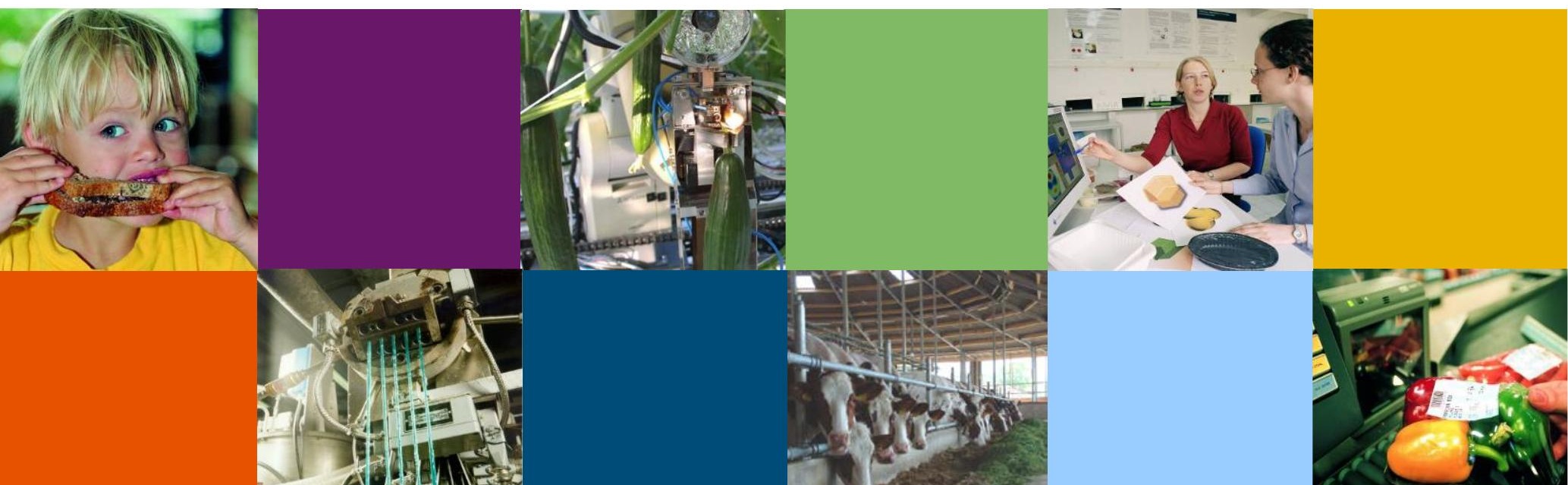




\section{Colofon}

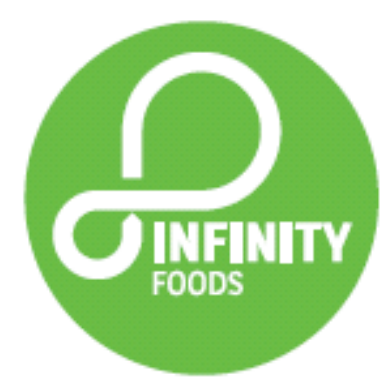

$\begin{array}{ll}\text { Titel } & \text { Eindeloos Groente } \\ \text { Auteur(s) } & \text { H.M. Vollebregt } \\ \text { Nummer } & \text { Wageningen Food \& Biobased Research } 1777 \\ \text { ISBN-nummer } & \text { 978-94-6343-813-1 } \\ \text { DOI } & \text { https://doi.org/10.18174/426504 } \\ \text { Publicatiedatum } & \text { Januari 2018 } \\ \text { Versie } & \text { Eindversie } \\ \text { Vertrouwelijk } & \text { Nee } \\ \text { Goedgekeurd door } & \text { Ben Langelaan } \\ \text { Review } & \text { Intern / extern } \\ \text { Naam reviewer } & \text { Ben Langelaan / PPS partners } \\ \text { Financier } & \text { Ministerie van Economische Zaken } \\ \text { Opdrachtgever } & \text { PPS Eindeloos Groenten }\end{array}$

Wageningen Food \& Biobased Research

P.O. Box 17

NL-6700 AA Wageningen

Tel: +31 (0)317480084

E-mail: info.fbr@wur.nl

Internet: www.wur.nl/foodandbiobased-research

(C) Wageningen Food \& Biobased Research, instituut binnen de rechtspersoon Stichting Wageningen Research Alle rechten voorbehouden. Niets uit deze uitgave mag worden verveelvoudigd, opgeslagen in een geautomatiseerd gegevensbestand of openbaar gemaakt in enige vorm of op enige wijze, hetzij elektronisch, hetzij mechanisch, door fotokopieën, opnamen of enige andere manier, zonder voorafgaande schriftelijke toestemming van de uitgever. De uitgever aanvaardt geen aansprakelijkheid voor eventuele fouten of onvolkomenheden.

All rights reserved. No part of this publication may be reproduced, stored in a retrieval system of any nature, or transmitted, in any form or by any means, electronic, mechanical, photocopying, recording or otherwise, without the prior permission of the publisher. The publisher does not accept any liability for inaccuracies in this report. 


\section{Samenvatting}

Efficiënt omgaan met grondstoffen is een van de belangrijkste pijlers om bij te dragen aan het voeden van de toenemende wereldbevolking. Het zo hoog mogelijk verwaarden van reststromen die ontstaan tijdens productie, distributie en consumptie van levensmiddelen kan hieraan een goede bijdrage leveren.

In de publiek private samenwerking Eindeloos Groenten heeft Wageningen Food \& Biobased Research (WFBR) samen met haar consortium partners aan dit onderwerp gewerkt met als visie 'Voedsel moet voedsel blijven'. Het onderzoek is uitgevoerd in 2013-2016.

Onderliggende rapportage geeft een samenvatting van de deelprojecten waaraan WFBR in de PPS heeft gewerkt. Specifiek betreft het onderzoek de volgende onderwerpen:

- Omvang van de reststromen: welke volumes komen waar wanneer beschikbaar?

- Fabriekslocatie en transport: wat is de beste locatie voor een verwerkingsfabriek voor reststromen, en wat zijn de verwachte transportkosten?

- Wat is de inhoud van de reststromen: welke componenten of inhoudsstoffen bevatten de reststromen?

- Life cycle analysis: welke milieu-impact heeft productie van componenten uit reststromen ten opzichte van andere manieren van produceren van deze componenten?

- Kwaliteit en toepassing van reststromen: welke meerwaarde hebben de groentes als eiwitbron en hoe verhoudt zich dit tot meer gangbare eiwitbronnen? Wat zijn eigenschappen van de wortelvezels die projectpartners gemaakt hebben (voorbeeld toepassing in hamburgers)? In welke producten worden al wortelvezels toegepast?

Meer informatie over de deelprojecten kan verkregen worden bij de projectpartners. Het PPS Eindeloos Groente consortium wordt bedankt voor het mogelijk maken van dit onderzoek. 


\section{Inhoudsopgave}

Samenvatting 3

1 Inleiding $\quad 6$

1.1 Aanleiding 6

$\begin{array}{lll}1.2 & \text { Doel rapport } & 7\end{array}$

1.3 Doelstelling project 7

$\begin{array}{lll}1.4 & \text { Afbakening } & 7\end{array}$

1.4.1 Groentesoorten 7

1.4.2 Gebieden 8

$\begin{array}{lll}1.4 .3 & \text { Sectoren } & 8\end{array}$

1.5 Opbouw rapport 8

2 Inventarisatie beschikbaarheid 10

$\begin{array}{lll}2.1 & \text { Aanpak } & 10\end{array}$

$\begin{array}{lll}2.1 .1 & \text { Deskstudie } & 10\end{array}$

$\begin{array}{lll}2.1 .2 & \text { Interviews } & 10\end{array}$

2.2 Resultaten 11

2.2.1 Per sector 11

$\begin{array}{lll}\text { 2.2.2 Per product } & 11\end{array}$

2.2.3 Per land 11

$\begin{array}{lll}2.2 .4 & \text { Per seizoen } & 12\end{array}$

3 Optimale logistiek $\quad 13$

$\begin{array}{lll}3.1 & \text { Aanpak } & 13\end{array}$

$\begin{array}{lll}\text { 3.1.1 Simulatiemodel } & 13\end{array}$

$\begin{array}{lll}3.1 .2 & \text { Scenario's } & 13\end{array}$

3.1.3 Aannames 14

3.2 Resultaten 15

3.2.1 Transportkosten 15

$\begin{array}{lll}3.2 .2 & \text { Verwerkingslocaties } & 16\end{array}$

4 Inhoudsstoffen 18

4.1 Aanpak 18

$\begin{array}{ll}\text { 4.1.1 Voedingsstoffenbestanden } & 18\end{array}$

$\begin{array}{ll}\text { 4.1.2 Wetenschappelijke literatuur } & 19\end{array}$

4.2 Resultaten 19

4.2.1 Visualisatietool 19

$\begin{array}{lll}\text { 4.2.2 Interessante componenten } & 20\end{array}$

4.2.3 Variaties van inhoudsstoffen 21

5 Levenscyclusanalyse (LCA) 22

5.1 Aanpak 22

$\begin{array}{lll}\text { 5.1.1 Levenscyclusanalyse } & 22\end{array}$ 
$\begin{array}{lll}\text { 5.1.2 Alternatieve productiemethoden } & 23\end{array}$

$\begin{array}{lll}5.1 .3 & \text { Aannames } & 23\end{array}$

5.2 Resultaten 24

$\begin{array}{lll}\text { 5.2.1 } & \text { Betacaroteen } & 24\end{array}$

$\begin{array}{lll}\text { 5.2.2 Vezels } & 26\end{array}$

6 Kwaliteit en toepassingen van reststromen 30

$\begin{array}{lll}6.1 & \text { Groenteresten als eiwitbron } & 30\end{array}$

6.2 Eigenschappen van voedingsvezels uit wortels 33

6.2.1 Eigenschappen wortelvezels 33

6.2.2 Toepassing wortelvezels in hamburgers 34

6.3 Voorbeelden levensmiddelen met wortelvezels 35

6.3.1 Marktintroducties met "carrot fibre" of "carrot fibre" 36

6.3.2 Onderzoek naar vezel als additioneel of vervangend ingrediënt 38 


\section{Inleiding}

\subsection{Aanleiding}

$\mathrm{Al}$ meer dan 15 jaar wordt gesproken over het verwerken van AGF reststromen uit deze sector. Er zijn een aantal manieren gerealiseerd om zulke reststromen te verwaarden, maar het gaat dan voornamelijk om toepassingen als diervoeder, compostering en vergisting. Hoewel deze manieren van verwerking minder laagwaardig zijn dan het storten en verbranden van reststromen, zijn deze toepassingen nog relatief laagwaardig.

De Ladder van Moerman (Figuur 1) geeft een hiërarchie aan van de manieren waarop voedselreststromen verwaard kunnen worden, waarbij toepassing voor humane voeding de meest hoogwaardige manier van verwerking is als het verlies van voedsel niet voorkomen kan worden.

Het Eindeloos consortium beoogt te laten zien deze hoogwaardige manier van verwerking van AGF reststromen binnen handbereik is, namelijk door de extractie van componenten (macronutriënten, vezels, phytochemicaliën / bioactive ingrediënten), conversie tot voedselingrediënten en wellicht farmaceutische toepassingen.

$\left.\begin{array}{l}\text { Van hoog- naar laagwaardiger verwaarding: } \\ \text { Preventie } \\ \text { Toepassing voor humane voeding } \\ \text { Converteerbaar voor humane voeding } \\ \text { Toepassing in diervoer } \\ \text { Grondstoffen voor de industrie } \\ \text { Verwerken tot meststof door vergisting } \\ \text { Verwerken tot meststof door composteren } \\ \text { Toepassen voor duurzame energie } \\ \text { Verbranden als afval } \\ \text { Storten (verboden) }\end{array}\right\}$-Afval

Figuur 1 Ladder van Moerman: verwaarding van reststromen gesorteerd van hoog-naar laagwaardiger.

Door het hoogwaardig verwerken van reststromen wordt een bijdrage geleverd aan de reductie van de hoeveelheid voedsel die voor menselijke consumptie verloren gaat. De onder druk staande AGF sector kan zo bovendien meer waarde creëren uit stromen die momenteel vooral tot kosten leiden.

Het Eindeloos Groenten consortium bestaat uit TOP BV, Van Rijsingen Groep, Bakers Basket BV, Bodec BV en Wageningen Food \& Biobased Research (WFBR, onderdeel van Wageningen UR). Het vierjarige PPS project wordt gesteund door de topsector AgroFood TKI-AF-12195. 


\subsection{Doel rapport}

Deze rapportage is een samenvatting van de verschillende deelrapportages die opgeleverd zijn binnen het project Eindeloos Groenten. De aanleiding (hoofdstuk 1.1), doelstelling (hoofdstuk 1.2) en afbakening (hoofdstuk 1.3) van het project als geheel zijn hieronder beschreven.

Dit eerste hoofdstuk wordt afgesloten met de opbouw van het onderzoek en deze samenvattende rapportage (hoofdstuk 1.4). De doelstellingen, afbakeningen en methoden van de afzonderlijke deelprojecten worden in de desbetreffende hoofdstukken toegelicht.

\subsection{Doelstelling project}

Het doel van het PPS project Eindeloos Groenten is om voedsel(ingrediënten) te maken en/of functionele of farmaceutische toepassingen te ontwikkelen vanuit reststromen van groenten. Het streven is om deze grondstoffen uit reststromen te winnen op basis van grootschalige industriële verwerking, waarbij de focus exclusief ligt op de hoogwaardigere benutting van groentereststromen.

\subsection{Afbakening}

Eindeloos Groenten is afgebakend wat betreft soorten groenten, verzamelgebieden en sectoren. Omdat het project zich richt op de meest hoogwaardige benutting van reststromen, worden verwerking tot diervoeder en biobrandstof buiten beschouwing gelaten.

\subsubsection{Groentesoorten}

In totaal is de haalbaarheid voor grootschalige verwerking tot hoogwaardige toepassing van de reststromen van een twintigtal groentesoorten geanalyseerd. De 20 groentesoorten zijn geselecteerd op basis van het jaarlijks vrijkomende volume en de vooraf verwachte potentie van de inhoudsstoffen van de reststromen. Het gaat om onderstaande groentesoorten:
1. tomaat
11. spinazie
2. paprika
12. rode kool
3. winterpeen
13. witte kool
4. bos- en waspeen
14. komkommer
5. uien
15. sperziebonen
6. knolselderij
16. doperwten
7. spruitkool
17. broccoli
8. aubergine
18. boerenkool
9. rode biet
19. groene kool
10. courgette
20. andijvie 


\subsubsection{Gebieden}

De gebieden waarin de reststromen potentieel verzameld en opgehaald kunnen worden is vastgesteld op circa zeshonderd kilometer van een potentiële verwerkingslocatie in Nederland. Hieruit volgt een afbakening van de volgende landen en gebieden:

1. Nederland

2. België

3. De volgende deelstaten van Duitsland: Sleeswijk - Holstein, Hamburg, Nedersaksen, Noord-Rijnland Westfalen, Hessen, Thüringen, Rijnland-Palts

\subsubsection{Sectoren}

Omdat het project toegespitst is op de industriële verwerking van groentereststromen, zijn binnen het project de te analyseren sectoren geselecteerd waar de grootste volumes reststromen vrijkomen:

1. Primaire productie: telers, kwekers en eerste sortering.

2. Handel: verdere sortering, verpakking, import en export, distributie.

3. Verwerking: industriële verwerking naar bevroren, ingeblikte of vers gesneden groente.

\subsection{Opbouw rapport}

Deze rapportage is een samenvatting van het onderzoek dat uitgevoerd is door WFBR in de periode 2013-2016 binnen de zeven individuele deelprojecten. De zeven deelprojecten zijn gericht op verschillende relevante aspecten welke belangrijk zijn bij het bepalen van mogelijkheden voor het grootschalig en hoogwaardig verwerken van groentereststromen. Deze zeven onderwerpen zijn:

1. Inventarisatie van de beschikbaarheid en omvang van groentereststromen.

2. Optimale logistiek bij verzameling van groentereststromen afhankelijk van het aantal locaties voor verwerking van de reststromen.

3. Omschrijving van de in de reststromen aanwezige inhoudsstoffen.

4. Levenscyclus analyse rondom de milieubelasting van het winnen van inhoudsstoffen uit groentereststromen in vergelijking met andere bronnen.

5. De kwaliteitsaspecten van de te verwerken reststromen op het gebied van gezondheid.

6. Ontwikkeling van technologie voor het verwerken van groentereststromen.

7. Disseminatie van het onderzoek.

In eerste instantie was wetgeving ook een apart deel van het onderzoek, maar in de eerste fase van dit deelproject bleek dat de relevante wetgeving erg case specifiek is en verder onderzocht moet worden als er specifieke cases gedefinieerd zijn. Werkpakket 6 , de ontwikkeling van technologie om groentereststromen te verwerken, ligt volledig buiten het door WFBR uitgevoerde onderzoek en wordt daarom niet in deze rapportage opgenomen. 
Figuur 2 geeft een overzicht van de zeven deelprojecten en de manier waarop ze met elkaar in verband staan. De resultaten uit de deelprojecten worden in de volgende zeven hoofdstukken chronologisch beschreven.

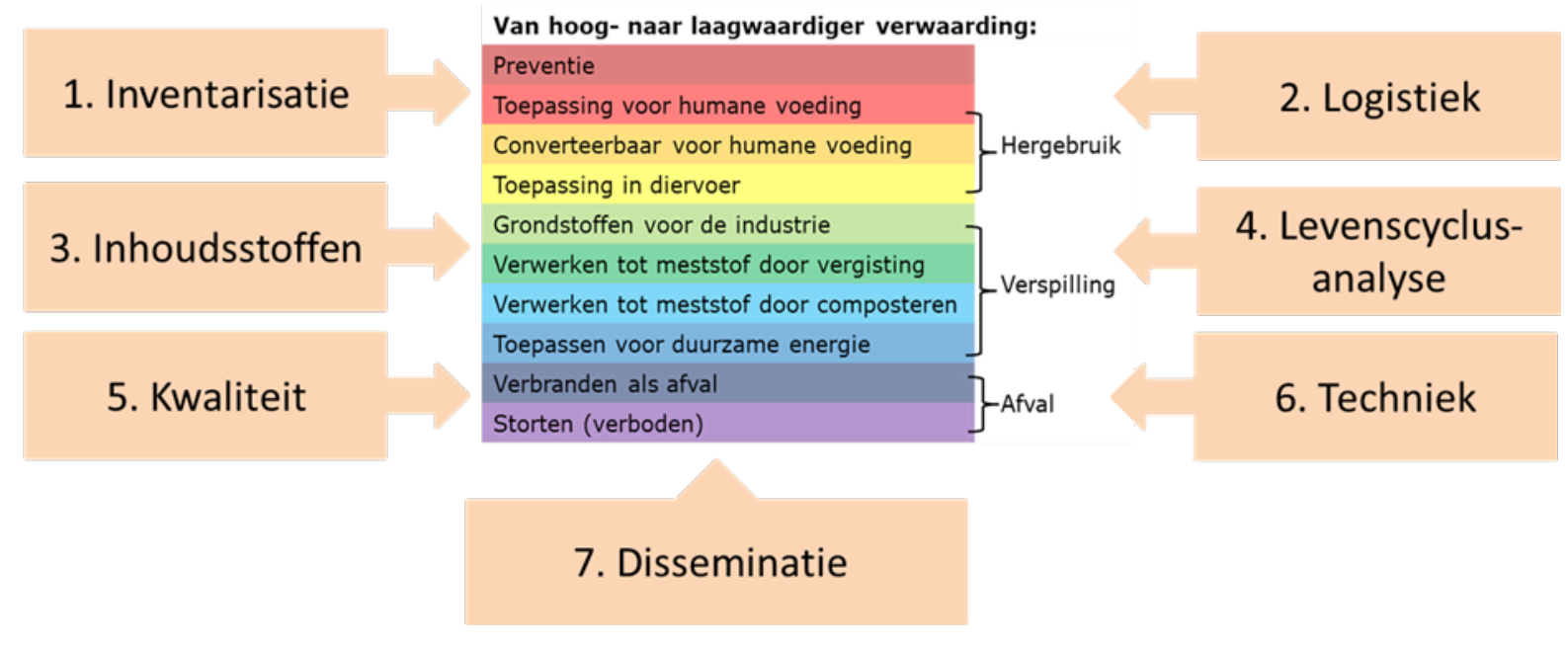

Figuur 2 Overzicht van de deelprojecten binnen de PPS Eindeloos Groenten.

Meer informatie over de deelprojecten kan verkregen worden bij de projectpartners. 


\section{Inventarisatie beschikbaarheid}

Voor verwarding van resten is het van belang om meer te weten over de beschikbaarheid van de reststromen. Aspecten als volume en locatie hebben invloed op schaal van verwerking en de logistiek en zijn hiermee bepalend voor de hoeveelheid groente die potentieel hoogwaardiger benut kan worden dan nu het geval is. Voor de 20 groenten is het volgende onderzocht. De locatie waar de reststromen ontstaan, zowel wat betreft de ketenschakel (primaire productie, handel of verwerkend industrie) als de geografische locatie van het desbetreffende bedrijf. De omvang van de reststromen per locatie waar ze ontstaan. En de variatie van de beschikbaarheid van reststromen door het jaar heen (seizoensinvloeden).

Sectie 2.1 beschrijft de aanpak in dit deelproject en sectie 2.2 geeft de resulterende cijfers.

\subsection{Aanpak}

De inventarisatie is uitgevoerd door middel van een deskstudie naar bestaande informatie in literatuur en in statistieken en door interviews met stakeholders in de primaire productie, handel en de verwerkende industrie.

De combinatie van bestaande informatie en informatie uit de interviews heeft het benodigde inzicht voor de geselecteerde groenten gecreëerd wat betreft de omvang, locatie en seizoenspreiding van de reststromen. Dit is gecombineerd met productie-, import- en verwerkingsvolumes uit statistieken van de drie landen om te komen tot kwantitatieve data voor de geselecteerde groentereststromen.

\subsubsection{Deskstudie}

De deskstudie bestond uit een literatuurstudie van bestaande publicaties over groentereststromen. De beschikbaarheid van kwantitatieve data over reststromen in bestaande wetenschappelijke en toegepaste literatuur is zeer beperkt, met name over individuele groentesoorten en de seizoenspreiding. Ook in nationale en sector-gerelateerde statistiek is informatie over (groente)reststromen beperkt.

\subsubsection{Interviews}

De interviews zijn gebruikt om betere inschattingen te maken van de omvang en de variatie van de reststromen per groentesoort. Daarnaast hebben de interviews ook informatie opgeleverd over samenstelling, bestemming, verwaarding en initiatieven tot vermindering van groentereststromen.

Voor de primaire productie sector zijn telers en kwekers van de 20 vollegronds- en kasgroenten benaderd, gedeeltelijk vanuit eigen netwerk, gedeeltelijk vanuit contactinformatie van een aantal websites. 
Voor de sectoren handel en verwerking (vers snijderijen, conserven en diepvries) is uitgegaan van bedrijfsinformatie van de Kamer van Koophandel voor Nederland; Fevia (Federatie Voedingsindustrie) en Vegebe (Federatie voor de Belgische Groente- en Fruitverwerking) voor België; en van de Schober database voor Duitsland.

De resulterende lijst met bedrijven is gesorteerd op bedrijfsomvang. De grootste bedrijven uit deze lijst die de relevante groentesoorten telen, verhandelen en/of verwerken zijn benaderd voor een interview, die telefonisch zijn afgenomen op basis van een gestandaardiseerde vragenlijst.

\subsection{Resultaten}

De teelt, handel en verwerking van de geselecteerde groenten resulteert in een volume van ongeveer 860.000 ton aan productresten. Deze omvang komt overeen met $12,5 \%$ van de productopbrengst in de primaire productie. In de primaire productie ontstaan ook gewasresten (bijna 1.100.000 ton, ofwel 15,9\% ten opzichte van de productie), die mogelijk ook interessant zijn om hoogwaardiger te benutten. In Eindeloos Groenten is alleen naar de productresten gekeken.

\subsubsection{Per sector}

Beschouwd voor de drie regio's samen is $41 \%$ van de groente reststroom afkomstig uit de primaire sector, $36 \%$ is te vinden in de handel en de overige $23 \%$ in de verwerkende industrie. In de industrie vindt de meeste uitval plaats in de diepvriessector, 17,8\%. De conserven genereert $3,4 \%$, en de snijderijen $2,4 \%$. De combinatie van de Nederlandse primaire productie en handel, de Belgische diepvriesindustrie en de Duitse primaire productie is goed voor $70 \%$ van de reststroom.

\subsubsection{Perproduct}

Wortelen (37\%) en uien (27\%) zijn de grootste producten in het totale volume van de productreststroom. Samen met witte kool (8\%) en tomaten (5\%) zijn wortelen en uien verantwoordelijk voor $76 \%$ van het volume.

\subsubsection{Per land}

De verdeling van de hoeveelheid groentereststromen per sector en per groentesoort verschilt over de landen. Verschillen tussen de landen worden veroorzaakt door verschillen in omvang in primaire productie, zowel in totaal als per product, en door verschillen in omvang in de handel en de verwerkende sectoren. Zo is er in Nederland relatief veel primaire productie, handel en wordt er veel groente vers gesneden. In België is een cluster van diepvriesbedrijven. 
Alle verzamelde informatie over de omvang, locaties en seizoenspreiding van groentereststromen is beschikbaar gemaakt in een Excel file die is voorzien van een aantal visualisatie functies. In één oogopslag worden zo eigenschappen van reststromen inzichtelijk. Op een kaart van Nederland, België en Duitsland kan de locatie en omvang van primaire productie of van productreststromen in primaire productie en/of handel en/of verwerking op provincie en deelstaat niveau per product of voor meerdere producten getoond worden.

\subsubsection{Per seizoen}

De procentuele verdeling van de totale reststroom over de sectoren kan voor één of meerdere landen en voor één of meerdere producten getoond worden. Ook de seizoenspreiding in volume van de reststroom, gesplitst in primaire productie, handel en verwerking kan voor één of meerdere landen en één of meerdere producten getoond worden. 


\section{Optimale logistiek}

Eindeloos Groenten heeft gewerkt aan grootschalige verwerking van reststromen, met sourcing van resten uit Nederland, België en het weten van Duitsland. In dit deelproject is bepaald wat een geschikte locatie voor een verwerkingsfabriek voor reststromen is gegeven de locatie en volumes van de reststromen zoals beschreven in hoofdstuk 2 . Het doel van de optimalisering is het verzamelen van de beschikbare groentereststromen met minimalisatie van de logistieke kosten.

Sectie 3.1 beschrijft de aanpak van dit deelproject en sectie 3.2 geeft de resultaten voor verschillende scenario's.

\subsection{Aanpak}

Er is een simulatiemodel ontwikkeld waarmee de logistieke kosten bepaald worden. Met behulp van scenario's worden de kosten gepresenteerd. Het model, de scenario's en de bijbehorende aannames zijn hieronder beschreven.

Wat producten betreft ligt de focus voornamelijk op wortelen (winter-, was- en bospeen), gezien het belang van de teelt, verwerking en verkoop van wortelen in het consortium. Vanwege het relatief grote volume zijn ook de reststromen van tomaten, paprika's, uien, kool en courgettes in overweging genomen.

De verwerkingslocatie die als uitgangspunt wordt genomen is Helmond, waar door een consortiumpartij nu al restwortelen worden verwerkt. De analyse is gebaseerd op de maand april, aangezien deze maand qua volumes representatief is voor het gehele jaar.

\subsubsection{Simulatiemodel}

Om de optimale potentiële verwerkingslocatie te identificeren, zijn verschillende scenario's gedefinieerd en geanalyseerd. Deze scenario's zijn gemodelleerd en doorgerekend in de simulatiesoftware IBM ILOG Transportation Analyst. Als input voor het model zijn de locaties en omvangen van groentereststromen gebruikt zoals die berekend zijn in de inventarisatie (zie Hoofdstuk 2).

\subsubsection{Scenario's}

In het deelproject zijn verschillende scenario's geformuleerd om inzicht te krijgen in de transportkosten van specifieke locaties en sectoren:

1. Verzameling en transport van alle wortelreststromen naar Helmond;

2. Verzameling en transport van reststromen van tomaten, paprika's en courgettes naar een optimale locatie;

3. Verzameling en transport van reststromen van uien naar een optimale locatie;

4. Verzameling en transport van reststromen van tomaten, paprika's, wortelen en uien naar Helmond; 
5. Verzameling en transport van reststromen van alle koolsoorten naar een optimale locatie;

6. Verzameling en transport van alle groentereststromen naar Helmond en naar een optimale locatie.

\subsubsection{Aannames}

Om de verzamelde gegevens over reststromen te vertalen naar de scenario's in het model zijn een aantal aannames gemaakt.

Vanwege de grote spreiding van de beschikbaarheid en de benodigde organisatie kunnen niet alle reststromen kunnen verzameld worden:

- Beschikbaarheidsfactor: van de groentereststromen van de sectoren primaire productie, handel en verwerking kan respectievelijk $80 \%, 50 \%$ en $70 \%$ opgehaald worden.

- Organisatiefactor: na inachtneming van de beschikbaarheidsfactor worden groentereststromen alleen opgehaald uit de provincies en deelstaten waar zich $80 \%$ van het totale volume voortdoet.

Tabel 1 geeft een overzicht van de volumes van de groentereststromen na toepassing van de beschikbaarheidsfactor en de organisatiefactor.

\begin{tabular}{|l|c|}
\hline & $\begin{array}{c}\text { volume reststromen } \\
\text { (kiloton per jaar) }\end{array}$ \\
\hline 1. Plant en product verliezen productie, handel en verwerking & 1,956 \\
\hline 2. Productverliezen productie, handel en verwerking & 860 \\
\hline 3. Toepassing van de beschikbaarheid en organisatie factor & 460 \\
\hline 4. Afbakening tot de twaalf geselecteerde groentesoorten & 400 \\
\hline waarvan primaire productie & 160 \\
\hline waarvan handel & 140 \\
\hline waarvan verwerking & 100 \\
\hline
\end{tabular}

Tabel 1: Overzicht van het geselecteerde reststroom volume voor de logistieke optimalisatie.

Er wordt onderscheid gemaakt tussen het verzamelen van reststromen van verschillende locaties van primaire productie in een provincie of deelstaat zelf (collectietransport) en het transporteren van samengevoegde stromen naar de uiteindelijke verwerkingslocatie (interregionaal transport). In de sectoren handel en verwerkende industrie zijn de volumes groot genoeg om per locatie één vrachtwagen volledig te vullen, zodat er geen collectietransport nodig is. Figuur 3 illustreert het verschil tussen collectietransport en interregionaal transport. 


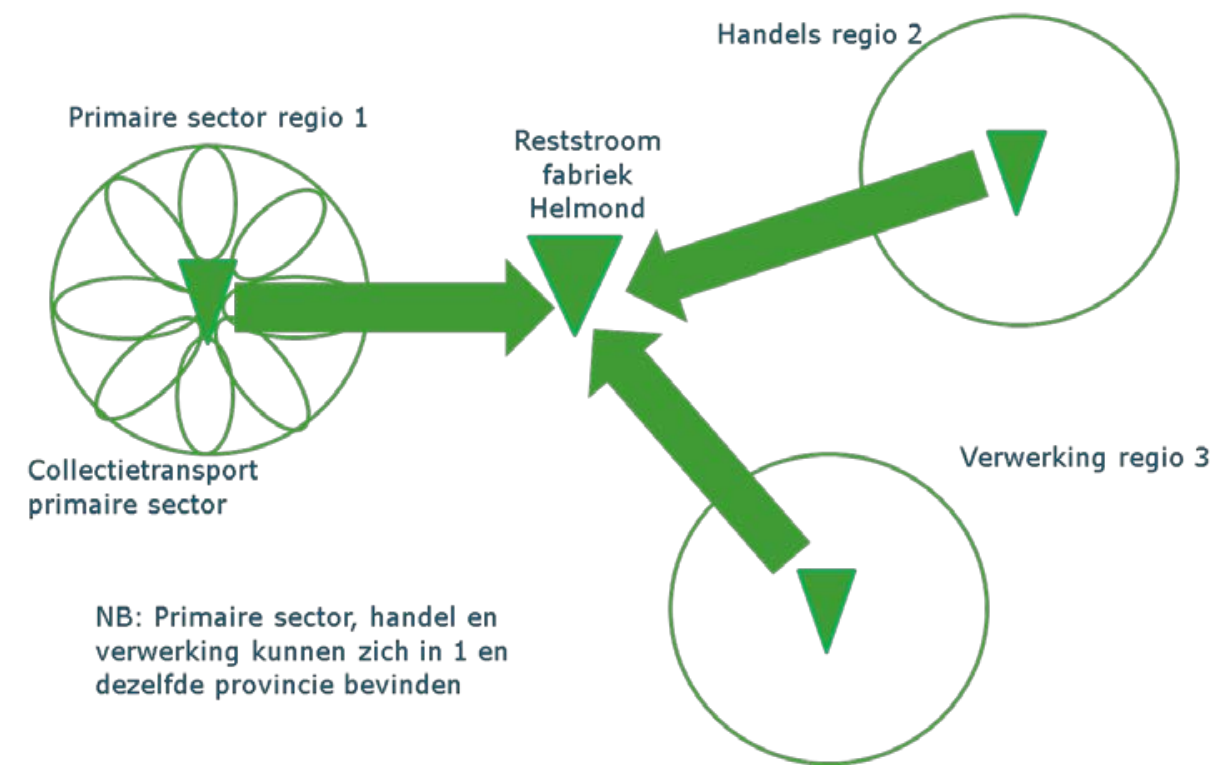

Figuur 3 Visualisatie van collectietransport (bet verzamelen van reststromen van verschillende locaties binnen één regio) en interregionaal transport (het transport van verzamelde reststromen naar éen verwerkimngslocatie).

\subsection{Resultaten}

De scenario's zijn geanalyseerd op resulterende transportkosten en locatie van de fabriek.

\subsubsection{Transportkosten}

Tabel 2 geeft de transportkosten weer van de groentereststromen afkomstig uit verschillende delen van het onderzochte gebied, waarbij onderscheid wordt gemaakt tussen collectietransport en interregionaal transport. Collectiekosten variëren van 14 tot bijna 20 euro per ton. Het verschil wordt veroorzaakt door het verschil in dichtheid van de primaire bedrijven waar reststromen beschikbaar komen in de verschillende regio's. Interregionale transportkosten liggen tussen de 4 en 30 euro per ton. Het verschil wordt veroorzaakt door de afstand tussen de verwerkingslocatie in Helmond en de regio's waar de reststromen vandaan komen. Het aantal break even kilometers geeft aan bij welke afstand de collectiekosten en interregionale kosten gelijk zijn.

\begin{tabular}{|l|c|c|c|c|}
\cline { 2 - 5 } & Collection & Inter-regional & \multicolumn{2}{c|}{ Collection versus inter-regional } \\
\hline Region & $€$ per tonne & $€$ per tonne & $\begin{array}{c}\text { Kilometres to } \\
\text { Helmond }\end{array}$ & $\begin{array}{c}\text { Break even } \\
\text { kilometres }\end{array}$ \\
\hline West Netherlands & 14.3 & 4.3 & 100 & 330 \\
\hline Rest of The Netherlands & 16.1 & 8.7 & 200 & 370 \\
\hline North West Belgium & 16.1 & 8.7 & 200 & 370 \\
\hline Rest of Belgium & 17.8 & 13.0 & 300 & 410 \\
\hline West Germany & 17.8 & 15.1 & 300 & 355 \\
\hline Rest of Germany & 19.6 & 30.1 & 600 & 390 \\
\hline
\end{tabular}


Tabel 3 geeft een overzicht van de totale en gemiddelde transportkosten per scenario. De gemiddelde transportkosten zijn met $€ 8,40$ per ton het laagst als alle kasgroenten naar één optimale verwerkingslocatie worden gebracht (er van uitgaande dat $80 \%$ van het totale aanbod verzameld wordt, scenario 2) en met $€ 27,50$ het hoogst als alle koolsoorten (brassica's) naar één optimale locatie worden getransporteerd (scenario 5).

\begin{tabular}{|c|c|c|c|c|c|}
\hline \multirow[t]{2}{*}{ Scenario } & \multicolumn{3}{|c|}{ Transportation costs } & \multirow{2}{*}{ Volume } & \multirow{2}{*}{$\frac{\text { Transport costs }}{\text { average }}$} \\
\hline & Collection & Inter-regional & Total & & \\
\hline Unit & \multicolumn{3}{|c|}{$1,000 €$} & 1,000 tonnes & $€$ per tonne \\
\hline \multicolumn{6}{|l|}{ Scenatio 1} \\
\hline 1a. $80 \%$ all Carrots to Helmond & 1,690 & 1,729 & 3,419 & 223 & 15.3 \\
\hline 1b. 33.3\% all Carrots to Helmond & 814 & 1,221 & 2,035 & 151 & 13.5 \\
\hline \multicolumn{6}{|l|}{ Scenatio 2} \\
\hline $80 \%$ all Greenhouse Vegetables to optimal location & 150 & 103 & 253 & 30 & 8.4 \\
\hline \multicolumn{6}{|l|}{ Scenario 3} \\
\hline $80 \%$ all Onions to optimal location & 549 & 664 & 1,214 & 121 & 10 \\
\hline \multicolumn{6}{|l|}{ Scenatio 4} \\
\hline 4a. 80\% Tomato, Sweet pepper, Carrot and Onion to Helmond & 2,440 & 2,478 & 4,917 & 339 & 14.5 \\
\hline 4b. $33.3 \%$ Tomato, Sweet pepper, Carrot and Onion to Helmond & 1,057 & 1,236 & 2,293 & 183 & 12.5 \\
\hline \multicolumn{6}{|l|}{ Scenario 5} \\
\hline $80 \%$ all Brassicas to optimal location & 1,083 & 968 & 2,051 & 75 & 27.5 \\
\hline \multicolumn{6}{|l|}{ Scenatio 6} \\
\hline 6a. $80 \%$ all Scenario $1-5$ vegetables to Helmond & 3,448 & 3,491 & 6,938 & 416 & 16.7 \\
\hline 6b. $80 \%$ all Scenario $1-5$ vegetables to optimal location & 3,448 & 3,133 & 6,580 & 416 & 15.8 \\
\hline
\end{tabular}

Tabel 3: Overzicht van de gemiddelde en totale jaarlijkse transportkosten per scenario.

In scenario 1 en 4 is ook gekeken naar de impact van het verlagen van de totale hoeveelheid reststromen die kan worden verzameld van $80 \%$ naar 33,3\%. In deze gevallen dalen de totale en de gemiddelde transportkosten, omdat dan alleen de grootste (en dus de snelst te verzamelen) volumes mee worden genomen.

\subsubsection{Verwerkingslocaties}

Als er niet wordt uitgegaan van de bestaande fabriek in Helmond als verwerkingslocatie van de reststromen, wordt er in het logistieke model een optimale, nieuwe verwerkingslocatie berekend. Deze optimale locatie komt tot stand door het minimaliseren van de transportkosten die nodig zijn om de geselecteerde groentereststromen naar deze locatie te vervoeren. De transportkosten en de locatie hangen dus af van de specifieke reststromen die verzameld worden. Dit heeft als gevolg dat de optimale locatie voor elke soort groentereststroom (of combinaties van verschillende stromen) anders kan zijn. 
De volgende scenario's zijn geanalyseerd op optimale locatie van de verwerkingsfabriek:

- Scenario 2: Verzameling en transport van reststromen van tomaten, paprika's en courgettes (ofwel alle geanalyseerde kasgroenten). De optimale locatie is nabij Woudrichem.

- Scenario 3: Verzameling en transport van reststromen van uien. De optimale locatie is nabij Mijdrecht.

- Scenario 5: Verzameling en transport van reststromen van alle koolsoorten. De optimale locatie is nabij Ottenstein;

- Scenario 6: Verzameling en transport van alle groentereststromen naar Helmond. De optimale locatie is ook in dit scenario nabij Woudrichem. 


\section{Inhoudsstoffen}

Welke verwaarding mogelijk is met een bepaalde reststroom wordt mede bepaald door de samenstelling van de reststroom: welke inhoudsstoffen bevat de reststroom welke mogelijk gewonnen kunnen worden?

De inhoudsstoffen geven de potentie aan van componenten die uit de verschillende groentereststromen door middel van extractie gewonnen kunnen worden en zo dus hoogwaardiger benut kunnen worden dan nu het geval is, zoals in voedingsmiddelen of farmaceutische toepassingen.

Groentesoorten verschillen wat betreft inhoud van macro- en micronutriënten. Hoe deze samenstelling is en waardoor deze beïnvloed wordt is van belang voor extractie en toepassing van deze inhoudsstoffen. Dit hoofdstuk geeft de gehaltes aan inhoudsstoffen en de variaties hierin voor de 20 groentes.

Sectie 4.1 beschrijf de aanpak van het deelproject en sectie 4.2 geeft een overzicht van de resultaten.

\subsection{Aanpak}

In dit deelproject is informatie uit voedingsstoffenbestanden en uit de wetenschappelijke literatuur gebruikt.

\subsubsection{Voedingsstoffenbestanden}

Gegevens over de nutritionele samenstelling van reststromen uit groenteproductie en -verwerking zijn niet rechtstreeks beschikbaar. Eetbare groentes zoals verkrijgbaar in de supermarkt zijn gekozen als model om de nutritionele samenstelling van groentereststromen weer te geven. Voor het rapporteren van de nutritionele samenstelling van de geselecteerde groenten is gebruik gemaakt van de volgende voedingsstoffenbestanden:

- Het Nederlands Voedingsstoffenbestand (NEVO). Dit bestand bevat de voedingswaarden van producten die in Nederland geconsumeerd worden.

- Aminozuren: USDA National Nutrient Database for Standard Reference.

- Flavonoïden: USDA Database for the Flavonoid Content of Selected Foods.

- Proanthocyanidinen: USDA Database for the Proanthocyanidin Content of Selected Foods. 


\subsubsection{Wetenschappelijke literatuur}

De gehaltes aan inhoudsstoffen kunnen variëren ten gevolge van diverse factoren. De benodigde informatie hierover is verkregen uit een quick scan van de wetenschappelijke literatuur. Zoals gemeld zijn er veel factoren die van invloed (kunnen) zijn op de gehalten voedingsstoffen en inhoudsstoffen. De wetenschappelijke literatuur over deze onderwerpen is echter gefragmenteerd; slechts zelden wordt het effect van alle bovengenoemde factoren die invloed hebben op de gehalten voedingsstoffen en fytochemicaliën in één studie vergeleken, laat staan de eventuele interacties tussen deze factoren. Dit bemoeilijkt het doen van kwantitatieve uitspraken over het effect van de bovengenoemde factoren.

\subsection{Resultaten}

Er is een visualisatietool ontwikkeld om de verzamelde informatie over inhoudsstoffen weer te geven, de meest interessante inhoudsstoffen zijn geïdentificeerd en de factoren die variaties van inhoudsstoffen beïnvloeden zijn geïnventariseerd.

\subsubsection{Visualisatietool}

De visualisatietool biedt de mogelijkheid om per component verschillende producten met elkaar te vergelijken, samen met de aanbevolen dagelijkse hoeveelheid (voor zover hierover informatie beschikbaar is). In Figuur 4 staat een voorbeeld van het lycopeengehalte in de verschillende groentes en aanverwante producten.

Met behulp van de visualisatietool is het bovendien mogelijk voor iedere afzonderlijke groente de samenstelling direct weer te geven in een aantal figuren. Figuur 5 geeft een voorbeeld met de macro- en micronutriënten samenstelling van tomaat. De data voor de twintig verschillende groentesoorten is aangevuld met informatie over in welke groente het hoogste gehalte van de betreffende inhoudsstof te vinden is om de gehaltes in perspectief te kunnen zien.

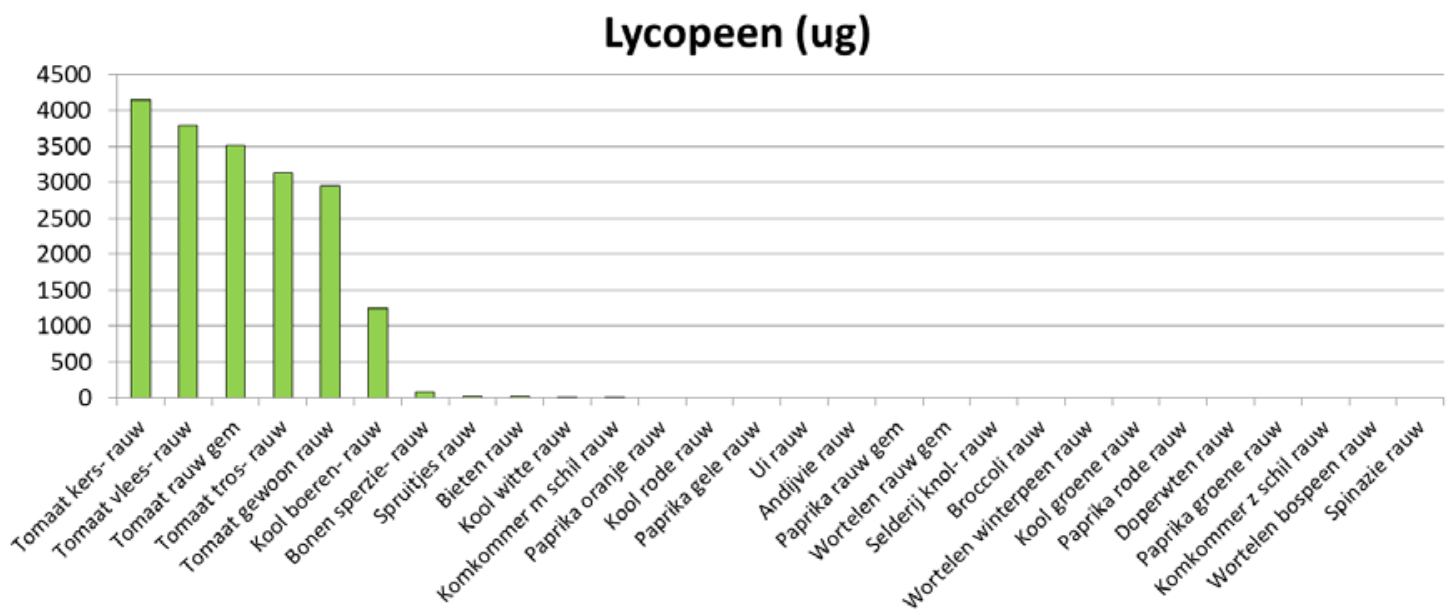

Figuur 4 Lycopeen gehalte (ug per $100 \mathrm{~g}$ eetbaar product) van verschillende groentes. 


\subsubsection{Interessante componenten}

Op basis van gehalten in de geselecteerde groenten is te concluderen dat de volgende componenten interessant zijn: voedingsvezel, en op basis van gehalte en ADH vitamine $\mathrm{C}$ en

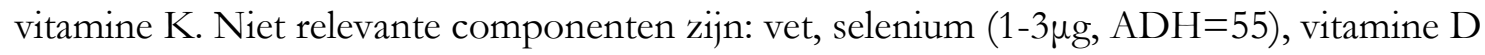
(afwezig) en proanthocyanidinen (afwezig).

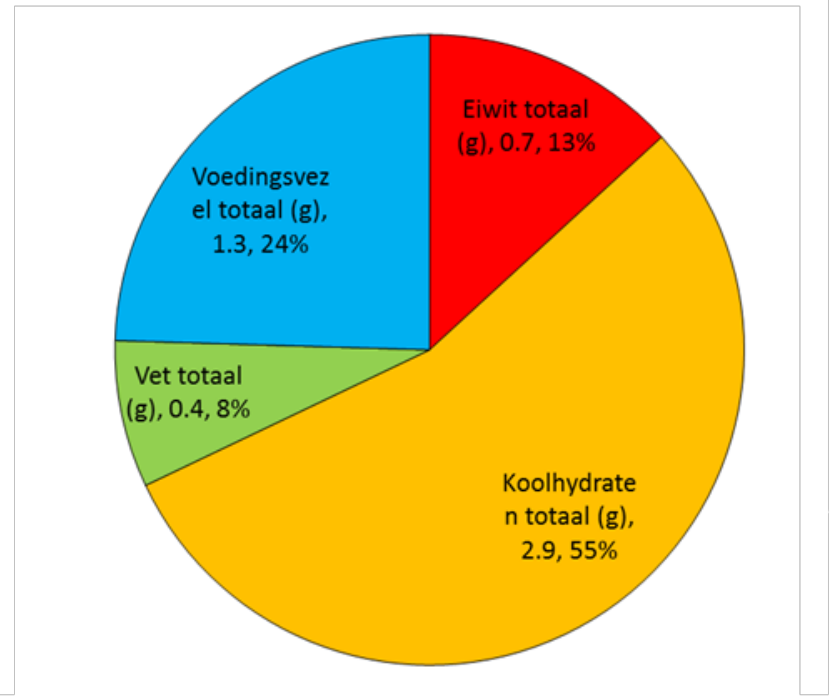

Amino Acid Content (mg)

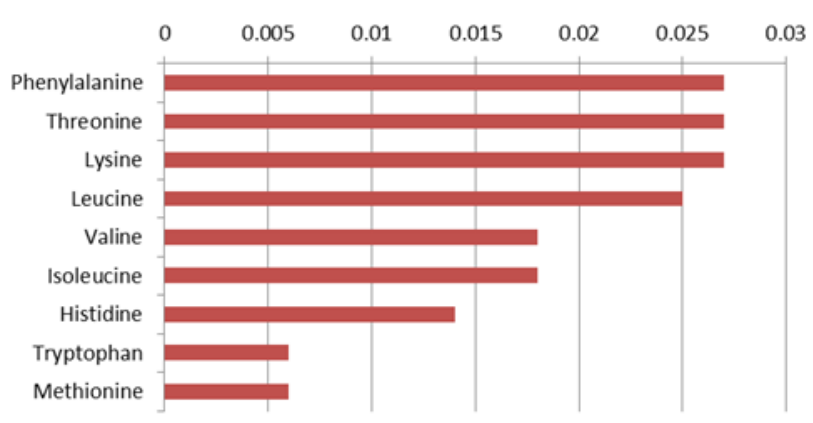

Flavonoid Content (mg)

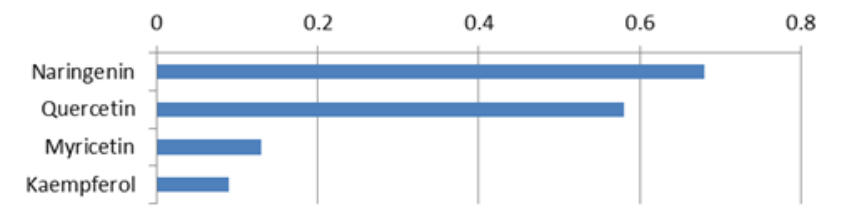

\section{Koolhydraten}

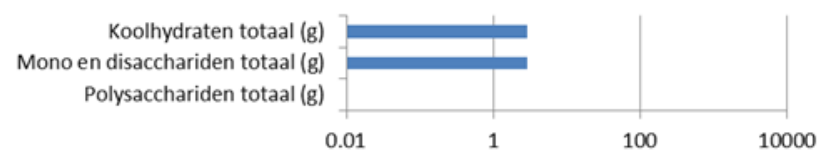

Mineralen

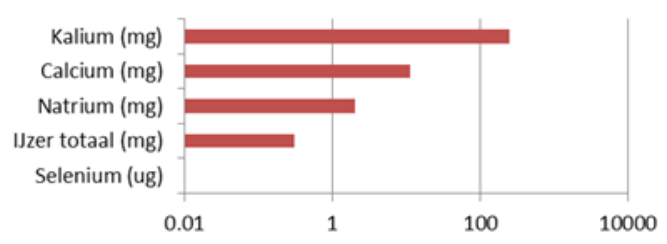

Vetten

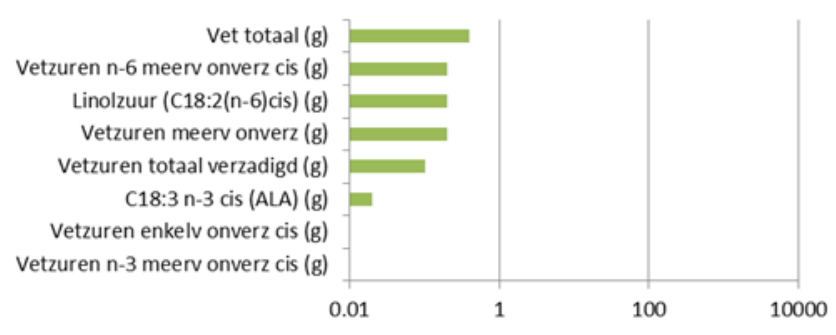

\section{Vitamines}

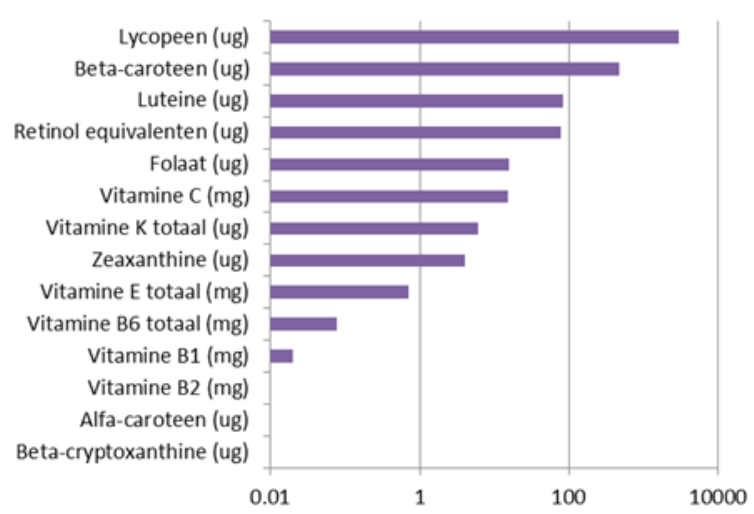

Figuur 5 Samenstelling rawwe tomaten. In macronutriënten (droog gewicht, vermelding gewricht (g) en percentage), koolhydraten, mineralen, vetten en vitamines (per 100gr eetbaar product, bron (RIVM 2013)) en aminozuren en flavonoïden (per 100gr eetbaar product, bron (USD A 2013)). 


\subsubsection{Variaties van inhoudsstoffen}

De gehaltes aan inhoudsstoffen kunnen variëren ten gevolge van diverse factoren:

- Effecten van opslag en verwerking.

- Locatie in het product.

- Effecten van variatie in ras en teelt.

- Gezondheidseffecten bij menselijke consumptie.

\section{Effecten van biologische variatie, invloed van teelt en seiroensinvloeden}

$\mathrm{Na}$ de oogst daalt over het algemeen de productkwaliteit en het gehalte nutriënten.

Wat betreft het effect van conventionele versus biologische teelt: dit is voor veel componenten niet eenduidig. Zowel hogere als lagere gehalten of geen effect worden gemeld. Verder kan het effect van rasverschillen groot zijn. Eveneens variëren gehaltes in de loop van het oogstseizoen.

\section{Locatie van de stoffen in het product}

De gehalten van componenten (kunnen) verschillen in de verschillende onderdelen (schil, pulp, sap) van de groenten, dit is afhankelijk van de functie van de inhoudsstof. Zo is voor de tomaat het lycopeengehalte het hoogst in de schil. Dit geldt ook voor het quercetinegehalte in de ui.

\section{Effecten van bewaring en verwerking}

Snijden, vermalen, persen, vriezen, ontdooien, koken en kauwen zorgen over het algemeen voor een daling in de gehalten componenten. Bij rijping is er bij sommige inhoudsstoffen een toename waarneembaar. Vitamine $\mathrm{C}$ is een gevoelige component, polyfenolen en carotenoïden zijn stabieler.

\section{Gezondheidseffecten bij menselijke consumptie}

Er wordt veel gepubliceerd over gezondheidsbevorderende effecten van groenten of de aanwezige componenten. Er is echter een gebrek aan eenduidige humane studies en de vraag bestaat of het gewenst effect te bereiken is met de in groenten aanwezige gehalten. 


\section{Levenscyclusanalyse (LCA)}

Het reduceren van de milieu-impact van voedselproductieketens is een van de motiverende factoren voor veranderingen in deze ketens. In dit deelproject zijn een aantal productieketens van producten uit reststromen op milieu-impact geanalyseerd met behulp van een life cycle analyses (LCA). De doelstelling van de analyse is om te bepalen of de winning van bepaalde stoffen, die anders verloren zouden gaan in een laagwaardige toepassing, een kleinere impact heeft op het milieu dan het produceren van deze inhoudsstoffen uit de groente reststromen.

Sectie 5.1 beschrijft de aanpak van het deelproject en sectie 5.2 geeft de resultaten.

\subsection{Aanpak}

De afbakening van dit deelproject bevat de verwerking van de reststromen van waspeen. Het gaat om alle activiteiten van de producent tot en met de fabrieksdeur ("cradle-to-gate"), aangezien de analyse zich richt op de milieu-impact van de productie en aangenomen wordt dat er geen verschil is in milieubelasting in de gebruiksfase.

De geanalyseerde inhoudsstoffen zijn vezels en betacaroteen, aangezien in deelproject Inhoudsstoffen bleek dat deze stoffen de meeste potentie hebben voor (rest)wortelen. De milieuimpact van deze manier van winning wordt vergelijken met alternatieve productiemethoden op basis van een levenscyclusanalyse.

\subsubsection{Levenscyclusanalyse}

Een levenscyclusanalyse geeft inzicht in de milieu-impact van een product gedurende zijn gehele levenscyclus (ook wel keten genoemd). Daarbij kunnen verschillende ketens met elkaar worden vergeleken, maar ook binnen een keten kan worden aangegeven wat de impact is van de verschillende onderdelen.

Een LCA bestaat uit verschillende onderdelen, in Figuur 6 zijn deze onderdelen weergegeven. Eerst worden het doel en de scope van de LCA bepaald, daarna wordt data verzamelt tijdens de zogenaamde inventory analysis. Vervolgens wordt de analyse van de milieu-impact uitgevoerd op basis van de verzamelde data; dit is de impact assessment stap. Alle onderdelen van een LCA zijn onderhevig aan de interpretatie, daarom moeten alle stappen goed worden onderbouwd en vastgelegd. Op basis van de complete analyse kunnen conclusies getrokken worden en de nodige gevoeligheidsanalyses worden uitgevoerd.

In deze LCA is gemodelleerd op basis van de ReCiPe Endpoint methode en er is gebruik gemaakt van de 'recycled content method'. 


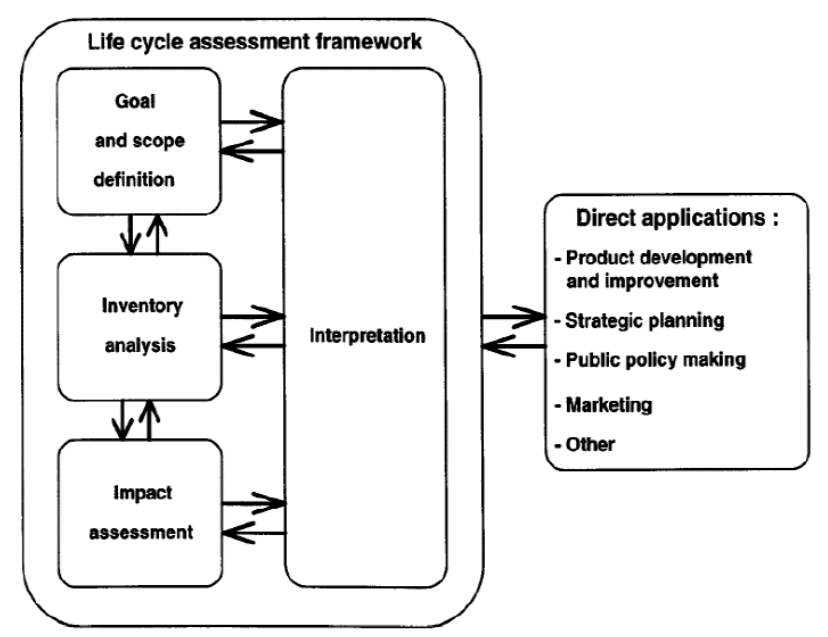

Figun 6 Onderdelen van een LCA volgens ISO.

\subsubsection{Alternatieve productiemethoden}

Er is gekozen een vergelijking te maken met andere productiemethoden uit natuurlijke ingrediënten, en dus niet synthetische productiemethoden, omdat dit de beoogde concurrerende producten zijn. De volgende ketens zijn daarom gedefinieerd:

Productie van bètacaroteen:

- Productie van bètacaroteen uit restwortelen van de wortelproductie en handel (keten 1a)

- Productie van bètacaroteen uit wortelen die speciaal hiervoor geproduceerd zijn (keten 2)

- Productie van bètacaroteen uit algen (keten 3)

Productie van vezels:

- Productie van vezels uit restwortelen van de wortelproductie en handel (keten 1b)

- Productie van vezels uit het restproduct van inulineproductie uit cichorei (keten 4)

- Productie van vezels uit citrus (keten 5)

De verschillende ketens worden met elkaar vergeleken op basis van de milieu-impact van het produceren van de functionele eenheid. Deze zijn als volgt voor de geselecteerde inhoudsstoffen:

- 10 gram bètacaroteenconcentraat met daarin 3\% bètacaroteen voor toepassing als kleurstof in de voedingsmiddelenindustrie.

- 50 gram vezels voor nuttige toepassing in de voedingsmiddelenindustrie.

\subsubsection{Aannames}

De belangrijkste gehanteerde aannames in de analyse zijn:

- Seizoensinvloeden: op het verbouwen en verwerken van groenten zijn seizoensinvloeden van toepassing. In deze studie worden de gegevens gemiddeld over een jaar, en worden de seizoensinvloeden dus niet meegenomen in de analyse. 
- Productvariëteit: aangezien het om natuurlijke producten gaat is er een zekere productvariëteit te verwachten. Dit kan bijvoorbeeld inhouden dat de concentratie inhoudsstoffen of de kwaliteit van het product verschilt per product of batch. In deze studie worden productvariaties niet meegenomen en is er gewerkt met gemiddelde waardes.

- Productielocatie: voor alle ketens wordt aangenomen dat er 1 productielocatie is.

\subsection{Resultaten}

De resultaten van de LCA zijn hieronder beschreven per inhoudsstof en per productiemethode.

\subsubsection{Betacaroteen}

De resultaten van de analyse van betacaroteen zijn opgesplitst naar productiemethode: uit restwortelen en uit algen. Vanwege het gebrek aan data is er voor de productie van betacaroteen uit speciaal gekweekte wortelen alleen een globale analyse gedaan. Ter illustratie is ook een vergelijking met de standaardproductie van ascorbinezuur (vitamine C) opgenomen.

\section{$\underline{\text { Restwortelen }}$}

De impact van de productie van bètacaroteen uit restwortelen is verdeeld over de verschillende productiestappen, zie Figuur 7. De grootste relatieve bijdrage komt van het maken van de pulp $(72 \%)$, gevolgd door het persen $(13 \%)$ en drogen $(9 \%)$.

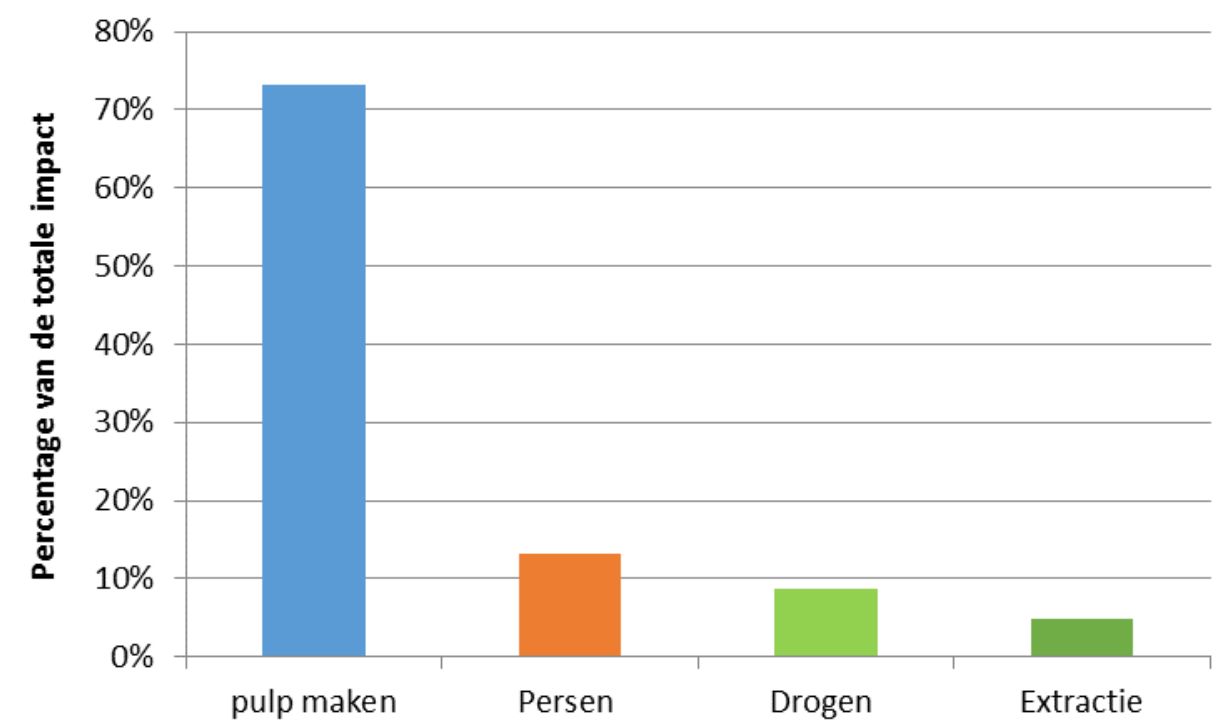

Figuur 7 Analyse van de milieu-impact van 10 gram betacaroteen uit restwortel.

Het merendeel van de impact van persen komt uit het gebruik van elektriciteit en hitte om te persen $(20,4 \%)$. Voor de productie van pulp en sap komt het grootste deel uit het gebruik van ascorbinezuur en citroensap concentraat (41\%). 


\section{$\underline{\text { Algen }}$}

De impact van de productie van bètacaroteen uit algen wordt vooral bepaald wordt door de extractie, zie Figuur 8. De grootste relatieve bijdrage komt van de extractie in eetbare olie (69\%), gevolgd door het oogsten (17\%), de algenproductie (10\%) en de celdisruptie (4\%). Purificatie is verwaarloosbaar.

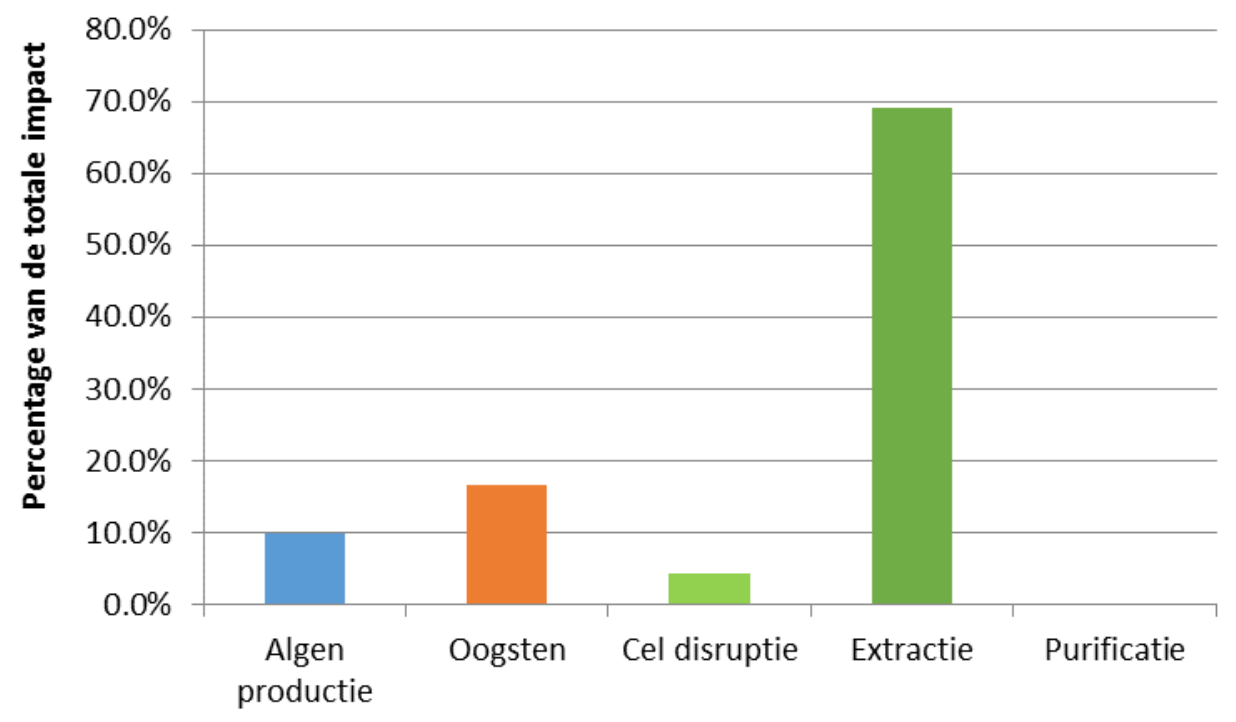

Figuur 8 Analyse van de milieu-impact van 10 gram bètacaroteen uit algen.

Het merendeel van de impact van de extractie komt door het gebruik van eetbare olie (69\%).

\section{Vergeliiking productiemethoden}

De impact van bètacaroteen wit algen is vele malen hoger is dan bètacaroteen wit andere productiemethoden en vitamine C, namelijk factor 7 groter dan bètacaroteen uit speciaal geteelde wortelen. Dit ligt aan het gebruik van olie voor de extractie. De impact van $6 \%$ bètacaroteenproductie uit restwortelen is grofweg 4\% van de impact van 3\% bètacaroteenproductie uit speciaal biervoor geteelde wortelen. De buidige vergelijking laat potentie zien voor bètacaroteen nit restwortelen.

Figuur 9 illustreert dit. 


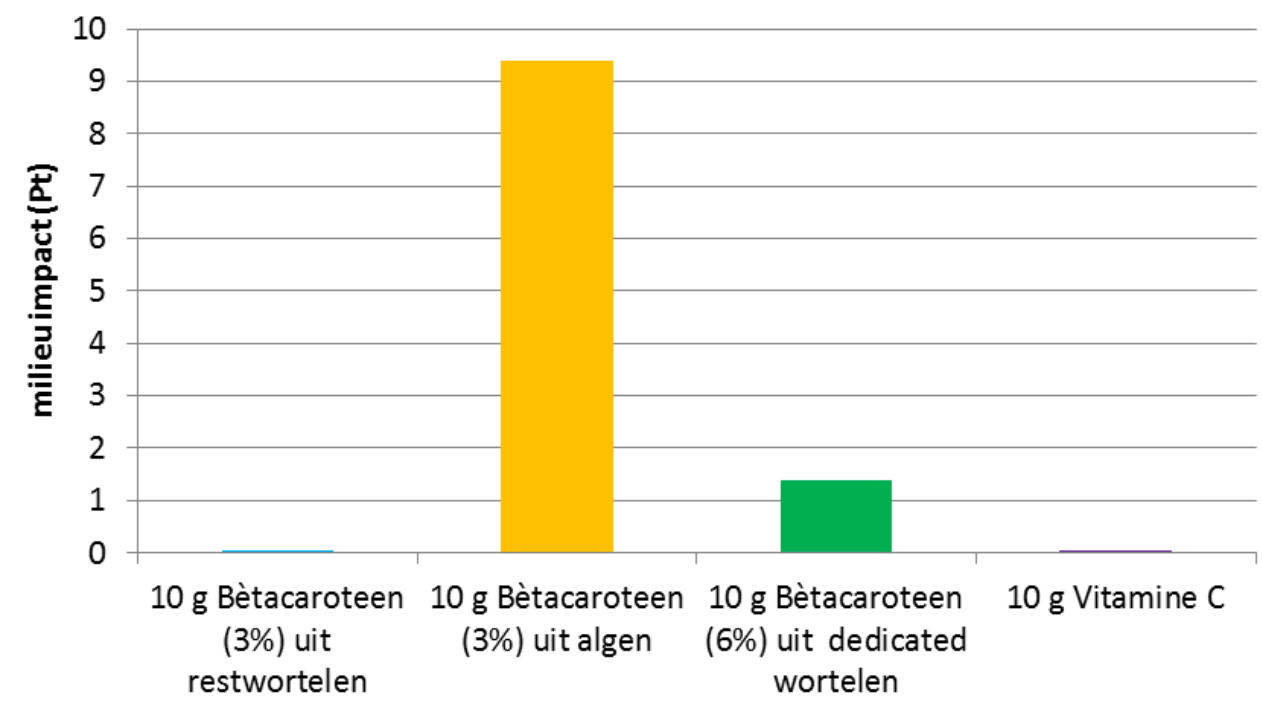

Figuur 9 Vergelijking tussen de drie productiemethoden van bètacaroteen en vitamine $C$.

\subsubsection{Vezels}

De resultaten van de analyse van vezels zijn opgesplitst naar productiemethode: uit restwortelen, uit cichorei en uit citrus. Ter illustratie is ook een vergelijking met de standaardproductie van bloem opgenomen.

\section{$\underline{\text { Restwortelen }}$}

De impact van de productie van vezels uit restwortelen is verdeeld over de verschillende productiestappen, zie Figuur 10. Net zoals bij de productie van betacaroteen uit restwortelen komt de grootste relatieve bijdrage van het maken van de pulp (72\%), gevolgd door het persen $(13 \%)$ en drogen $(9 \%)$.

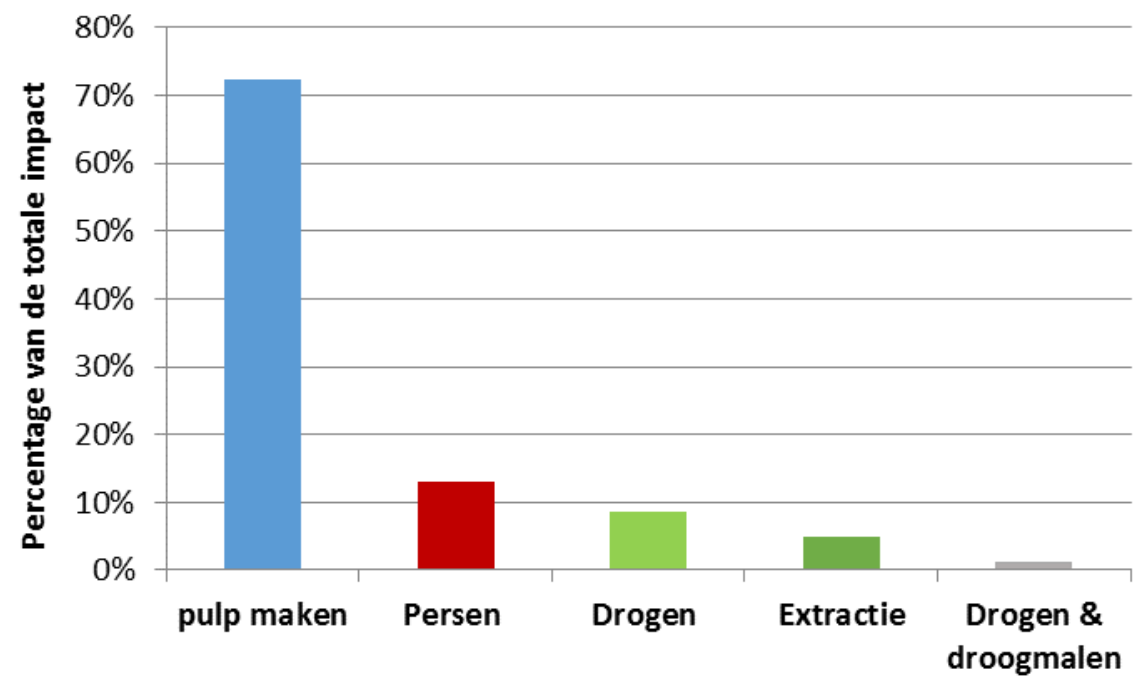

Figuur 10 Analyse van de milieu-impact van 50 gram vezels uit restwortel. 
Ook in dit geval komt de meerderheid van de impact van persen komt uit het gebruik van elektriciteit en hitte om te persen $(20,4 \%)$ en het gebruik van ascorbinezuur en citroensap concentraat $(41 \%)$ voor de productie van pulp en sap.

\section{Cichorei}

Het grootste deel van de impact van vezels uit cichorei wordt veroorzaakt door het persen van de pulp (91\%) en een klein deel door het drogen (8,9\%), zie Figuur 11. Dit komt beide door het elektriciteitsverbruik.

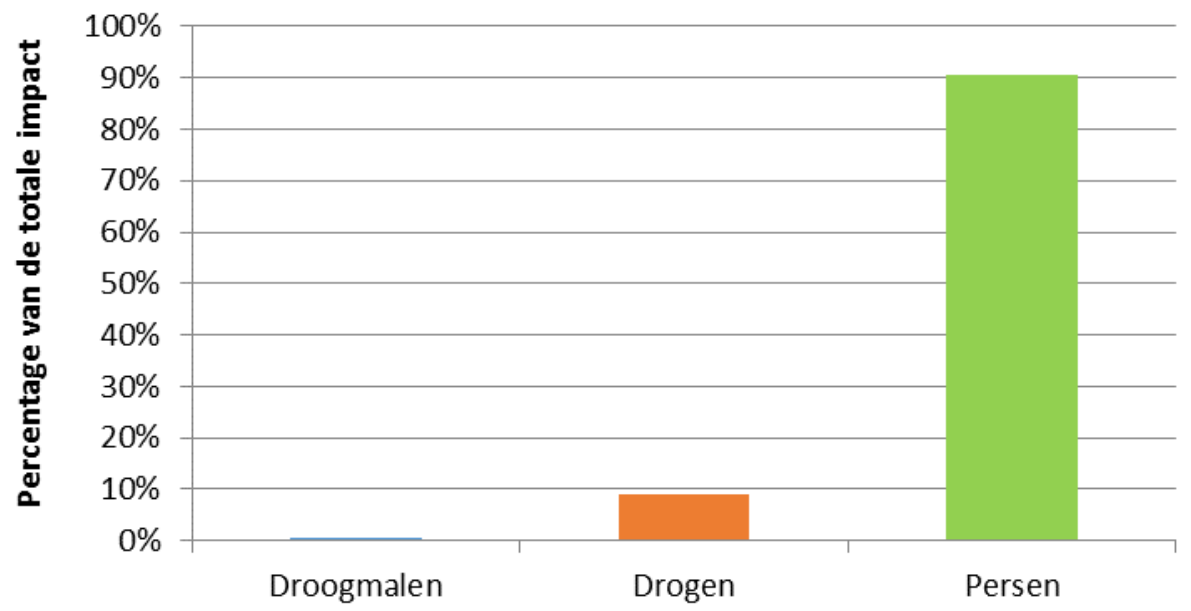

Figuur 11 Analyse van de milieu-impact van vezels uit cichorei en de relatieve bijdrage van de verwerkingsprocessen.

\section{Citrus}

De productie van vezels uit citrus is momenteel de standaard productie. De grootste bijdrage aan de impact van vezels uit citrusvruchten komt van de elektriciteit die nodig is voor het verpulveren van de rauwe, gewassen citrusschillen $(32 \%)$ en voor het persen van de gekoelde, verpulverde citrusschillen (39\%). Daarnaast zijn ook het wassen van de rauwe citrusschillen (9\%) en het transport van productielocatie Spanje naar Nederland (13\%) van belang voor de totale impact. Figuur 12 illustreert dit. 


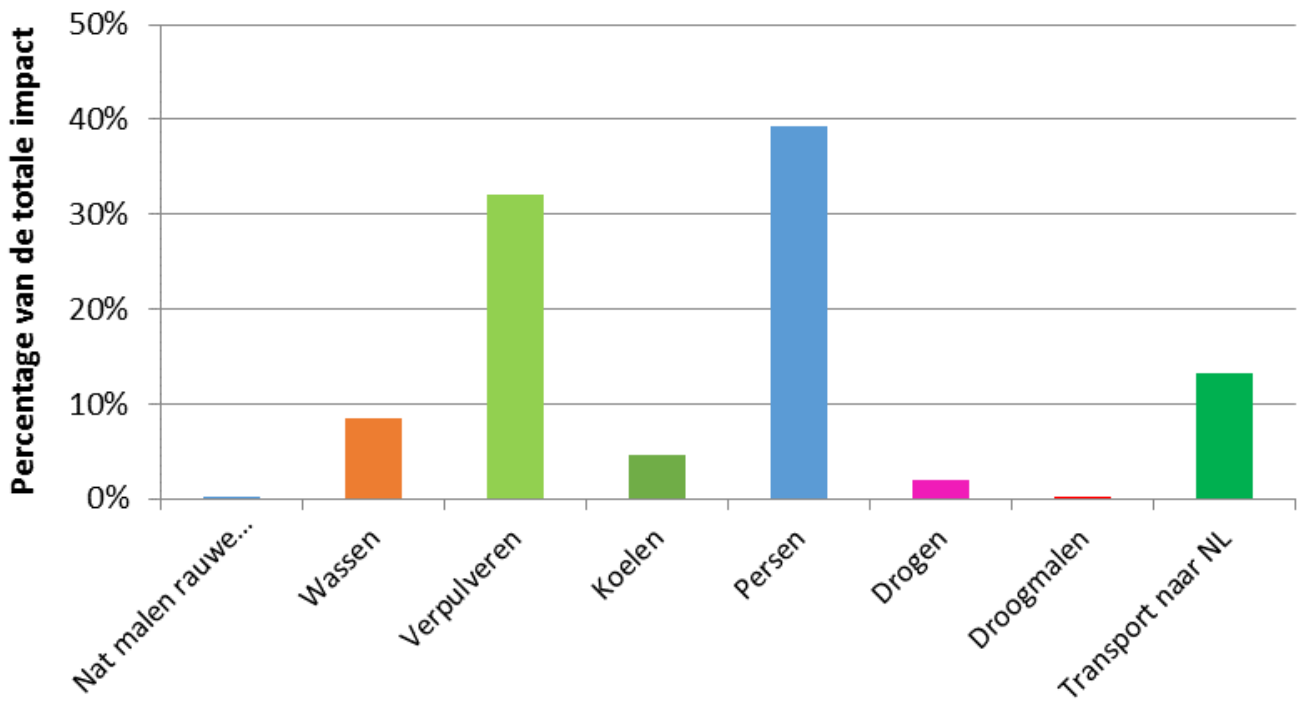

Figuur 12 Analyse van de milieu-impact van vezels wit citrus en de relatieve bijdrage van de verwerkingsprocessen

Vergelijking productiemethoden

Een vergelijking tussen de drie productiemethoden van vezels laat zien dat de vezels uit citrus voor de grootste impact zorgen. Met deze impact als uitgangspunt zorgen vezels uit cichorei voor slechts 3\% van dergelijke impact en vezels uit restwortelen $8 \%$. De citrusdata zijn echter gebaseerd op een labstudie. Dit zou kunnen verklaren waarom de keten zo hoog scoort op milieu-impact; in een labopstelling zijn processen nog niet geoptimaliseerd en wordt meer energie verbruikt dan bij een grote fabrieksopstelling.

Om de vezelproductie in perspectief te plaatsen, is er een vergelijking gemaakt met de productie van $1 \mathrm{~kg}$ bloem. Er wordt vanuit gegaan dat gemiddeld 10-50 gram vezels wordt toegevoegd aan $1 \mathrm{~kg}$ tarwe bloem. Uit de vergelijking blijkt dat 50 gram vezels uit citrus meer dan half zo veel impact beeft dan $1 \mathrm{~kg}$ bloem, zie

Figuur 13.

De huidige vergelijking laat potentie zien voor vezels uit restwortelen en cichorei. Verder onderzoek is nodig voor meer duidelijkheid over de verschillen in milieu-impact tussen de ketens. 


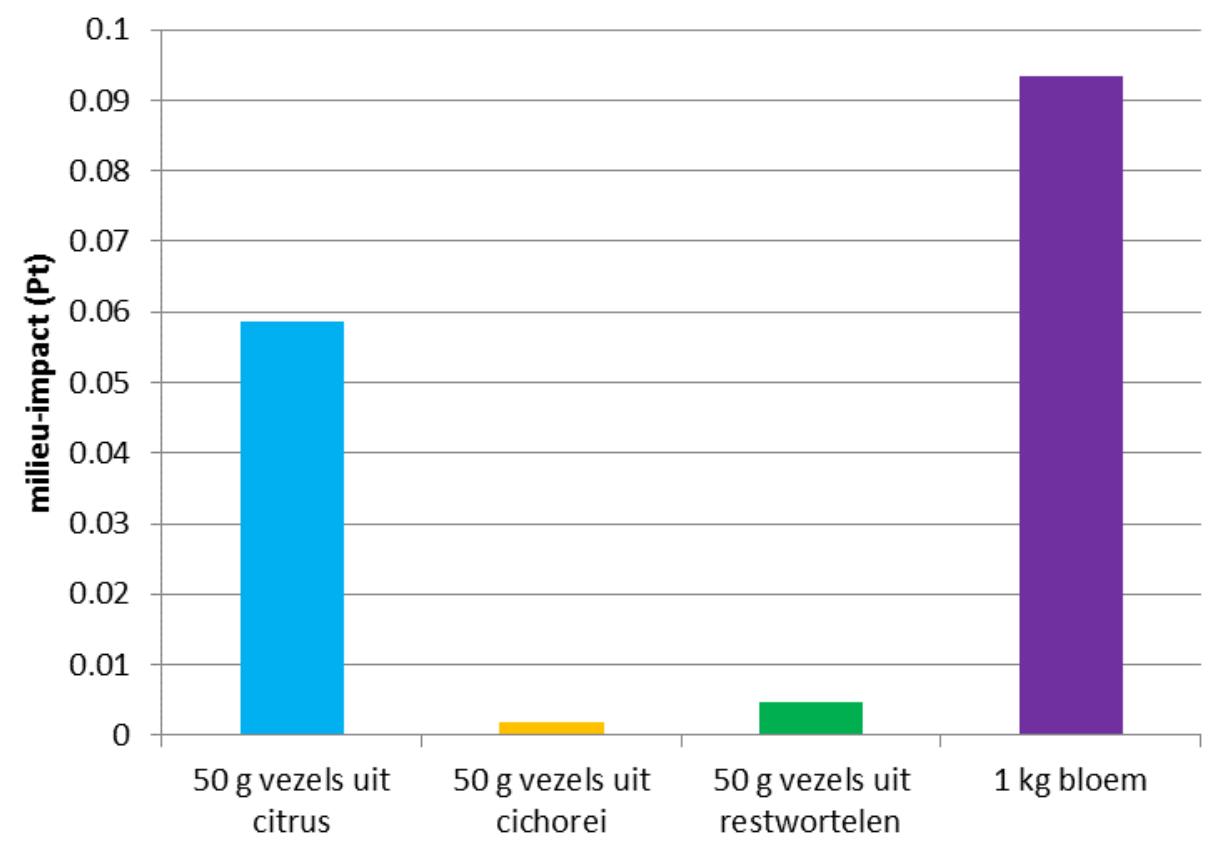

Figuur 13 Vergelijking van de milieu-impact van de drie vezeltypes en bloem. 


\section{$6 \quad$ Kwaliteit en toepassingen van reststromen}

In het project Eindeloos Groenten zijn een aantal onderwerpen ondergebracht onder de noemer 'Kwaliteit en toepassingen van reststromen'. Dit hoofdstuk geeft een samenvatting van resultaten op 1) groentereststromen als eiwitbron (sectie 6.1), 2) eigenschappen van voedingsvezels uit restwortelen (sectie 6.2), 3) overzicht bestaande voedingsmiddelen met vezels uit wortels en productvoorbeelden uit de wetenschappelijke literatuur (sectie 6.3) en 4) koppeling inhoudsstoffen en functionele eigenschappen (sectie 6.4).

De potentie om groenteresten als eiwitbron te gebruiken is in kaart gebracht samen met het project IEA Bioenergy - Task 42 Biorefinery. Het onderzoek naar eigenschappen van vezels uit wortels is uitgevoerd in twee afstudeerprojecten van de vakgroep Food Process Engineering en de vakgroep Food Quality \& Deign van Wageningen UR. Beide onderdelen zijn daarom in het Engels opgesteld.

\subsection{Groenteresten als eiwitbron}

As the world population increases so does the necessity for a sustainable protein supply, both for food and feed applications. Therefore, world-wide, there is a search for new protein sources, such as micro-algae, grasses, lupine, leaf material, press cakes from oil seeds and insects. By far, the highest quantity of proteins is being used in the feed sector. In comparison to the feed market, a relatively small amount of protein concentrates and isolates are being used in food applications. Finally, the number of proteins in bio-based applications, such as coating, adhesives and green chemicals, is very limited.

Figure 14 gives the protein content of the 20 vegetables of interest in comparison to three reference products: quinoa, soy bean and chickpea. Next to the protein content also the total amino acid content, the percentage of essential amino acids present and (as an example) their lysine content have been investigated.

Interestingly, the protein content of spinach and broccoli is similar to that of soy bean. All selected vegetables possess a good amino acid composition. The share of essential amino acids in soy and chickpea is similar (37\%), and in quinoa almost 40\%, while that of spinach, endive, green peas, snap beans, carrots, and broccoli is even higher than quinoa. Spinach is also an interesting product as a source for amino acid extraction. Its share of essential amino acids is the highest of all selected products. Soy beans have the highest lysine content. Courgettes spinach, broccoli and green peas have a lysine content higher than or similar to that of chickpea. 


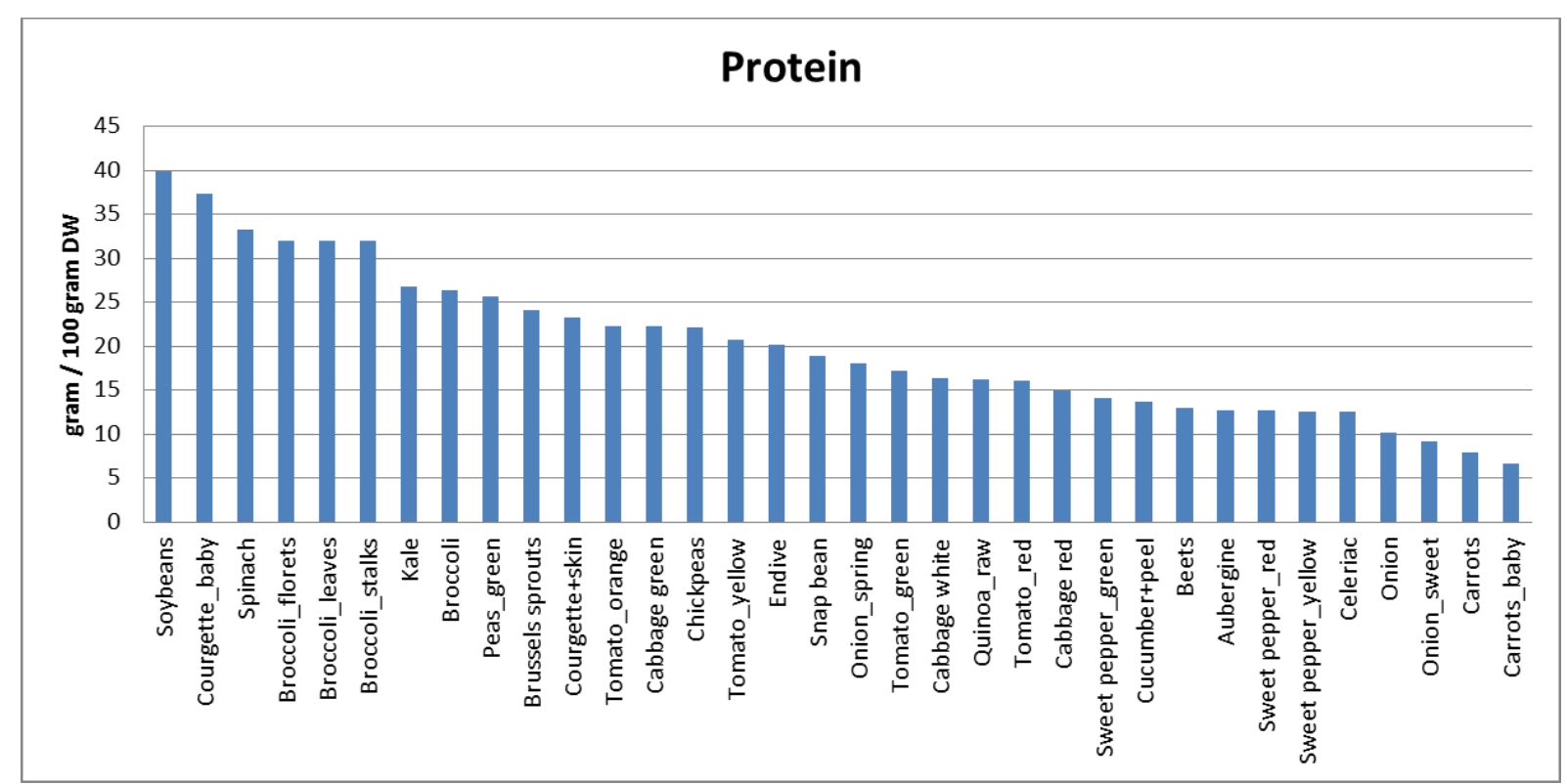

Recalculated to dry weight (DW) using compositional data from USDA national nutrient database sr28 (sep 2015) and sr26 (2013).

Figuur 14 Comparison of protein content of vegetables of interest with three reference products: quinoa, soy bean and chickpea.

Furthermore, pea has been evaluated for its applicability as a protein resource and its options for replacing soy bean. Although currently, the major application for pea residues is in feed, an increasing importance of pea residues for food is foreseen. Pea can be used as such when milled, or after fractionation. This typically yields a concentrate after dry separation (air classification) or an isolate after wet milling. As the first method gives a more functional protein, pea concentrates can be used for their functional properties. However, off-flavour is an important issue when more than $10 \%$ of pea concentrate is introduced in new products. This may be circumvented by using pea isolates, which have higher purity. However, due to the extraction method pea isolates have lost most of their functionality and are therefore mainly applied if food products for their nutritional value.

In Figure 15 vegetables are sorted by their reported waste stream volume, see Chapter 2 . The reported waste stream volumes of carrots is highest, followed by onion and white cabbage. The protein content of carrots and onions however (7-10\%), is much lower than that of soybean, chickpeas and quinoa. Because of its high protein content spinach might be an interesting alternative product as a source for protein extraction. 


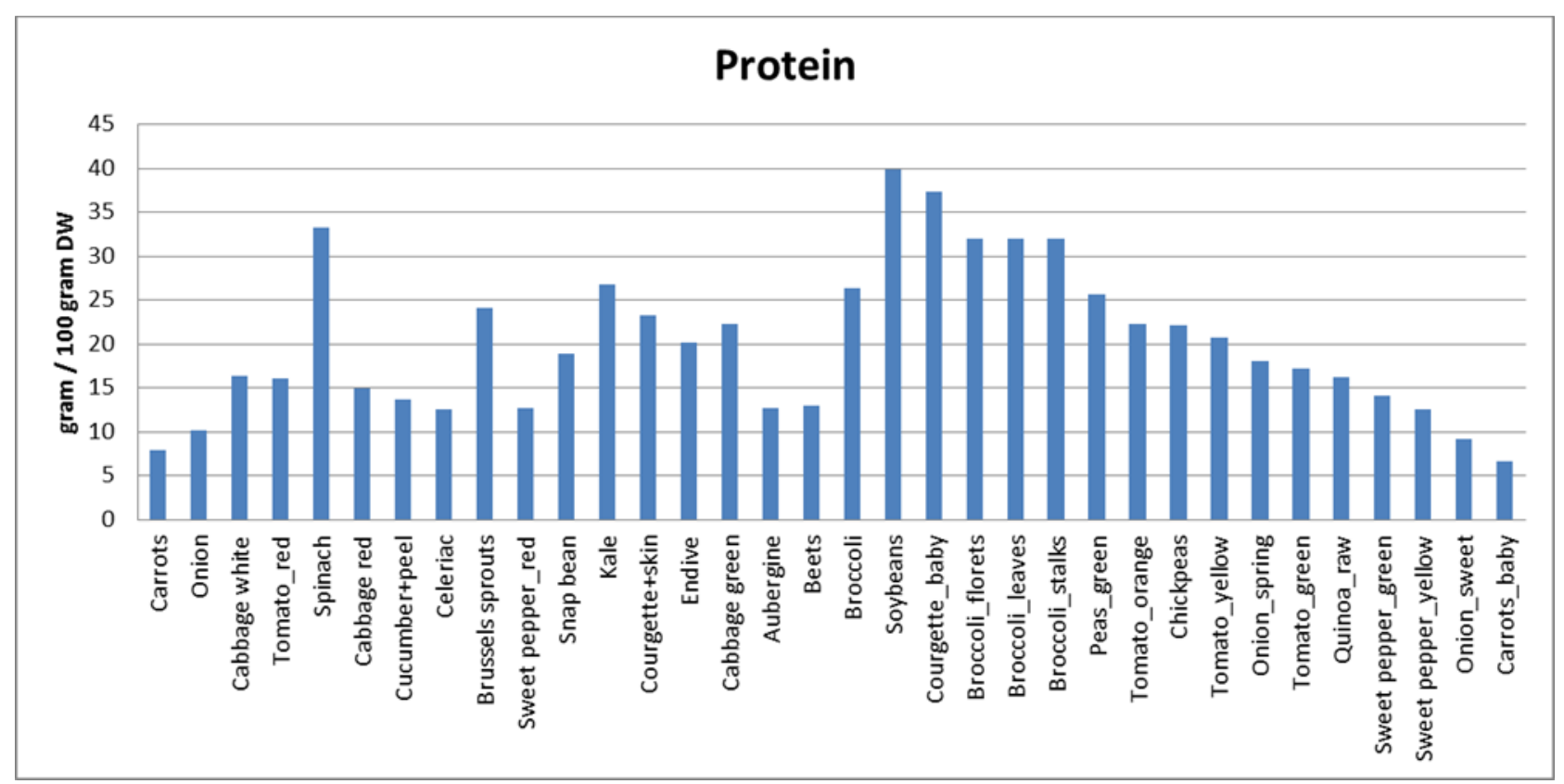

Recalculated to dry weight (DW) using compositional data from USDA national nutrient database sr28 (sep 2015) and sr26 (2013). Sorted by waste stream volume, from carrots until broccoli. From the other products volumes are not available.

Figuur 15 Comparison of protein content of vegetables of interest in the Infinity project with three reference products: quinoa, soy bean and chickpea. Products are sorted by waste stream volume, carrot having the bighest volume.

Protein consumption by humans is based on the consumption of meat, dairy products and protein crops, such as legumes and bread. The prices of these protein crops generally range between 0.10 and $0.50 € / \mathrm{kg}$. A relatively small amount of proteins, for example soy protein and wheat gluten, are being extracted from these crops and used as functional proteins (most important: high water-solubility) in food formulations. The status of currently used protein concentrates and isolates is described in this report. For soy protein, wheat gluten and pea protein the productions processes are given. The prices of these pure plant proteins range between 2 and $4 € / \mathrm{kg}$. Important to mention is that most of the proteins that are used in food are storage proteins. The vegetables selected in Infinity project, with the exception for peas, do not contain these kind of storage proteins. For feed, amongst others, protein-containing side streams from several industries are being used, such as the press cakes from the oil industry and side streams that are generated at bio-ethanol production, like dried distillers grain (DDG). Prices of the sources for feed range between 0.1 and $0.5 € / \mathrm{kg}$.

The possible outlet of proteins, towards food, feed or bio-based applications, is strongly dependent on the functionality of the proteins. Proteins with low functionality can be used as amino acid source in feed formulations or as peptides in technical applications. In general, it can be stated that the prices of proteins for bio-based applications are between those for feed and, for proteins in isolated form, for food. For the calculation of business cases in which proteins are involved, a price of $1 € / \mathrm{kg}$ can be a starting point. 
An important issue for food applications is the restriction of extracted and isolated proteins which have not been used in food so far. These "new" proteins have to pass the Novel Food regulation law. Therefore, the outlet of new proteins in bio-based applications could be more feasible in the short term.

Also relatively new biorefinery initiatives exist with the focus on the extraction and isolation of proteins from different biomass. Press cakes in general contain about $50 \%$ protein. Due to the oil extraction process by hexane, the proteins are denaturated to a large extent, resulting in meals with a high content of insoluble proteins. Therefore, the main outlet for press cakes is in animal feed. In contrast to the extraction of proteins from oil seeds and starch crops, the extraction from herbaceous materials and aquatic biomass is more difficult and for example more effort is needed in disruption of cell walls.

\subsection{Eigenschappen van voedingsvezels uit wortels}

Er zijn twee afstudeeropdrachten in samenwerking van de vakgroepen van Wageningen UR uitgevoerd binnen het Eindeloos Groenten project. Sectie 6.2.1 geeft een samenvatting van het onderzoek aan eigenschappen van de vezels welke door Van Rijsingen geproduceerd zijn. In sectie 6.2.2 wordt een onderzoek naar toepassing van wortelvezels in hamburgers samengevat..

\subsubsection{Eigenschappen wortelvezels ${ }^{1}$}

In the food industry side streams can contain valuable components; such as dietary fibres, vitamins, minerals and bioactive compounds like flavonoids, lycopene or carotenes. The producers can upgrade the side stream to create new food ingredients that will add to the product nutritional (bio-active compounds) and non-nutritional (fibre) value.

The carrot side stream samples were obtained after juice production. One sample was fresh pulp, several other samples were fluidized bed dried pulp with different drying temperatures and for comparison a commercial product was taken into account. The material was tested in water holding capacity, viscosity and dietary fibre content. It must be noted that there are different methods for all three properties and results must be presented with specification of the used method. Figure 16 shows a picture of fresh carrot pulp and of milled dried pulp.

The carrot samples showed the same water holding capacity as the commercial sample. Also the dietary fibre had a soluble/insoluble fibre ratio appropriate to be used as a food ingredient.

Several product with carrot fibres powder as ingredient are already on the market. Worldwide most of them are included in the categories 'Sauces and seasonings' and 'Meat, fish and eggs'. In the European market most of the launches correspond to the 'Spreads' category.

\footnotetext{
${ }^{1}$ Sanchez, Z.A., Upgrading of carrot (Cuacus Carota L. ssp. Sativa) and white asparagus (Asparagus officinalis L.) side stream, master thesis Food Process Engineering, Wageningen University, 2016.
} 

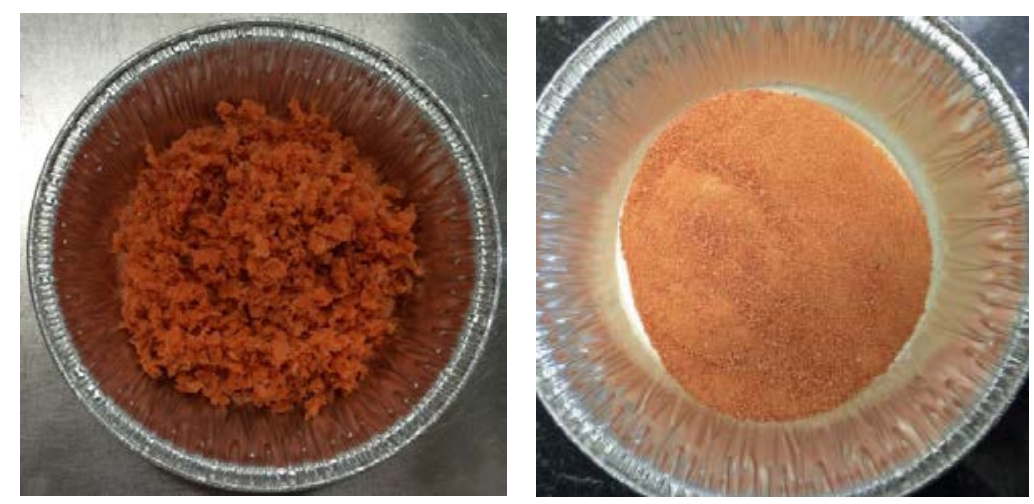

Figuur 16 Fresh carrot pulp (lieft) and milled dried carrot pulp (right).

\subsubsection{Toepassing wortelvezels in hamburgers ${ }^{2}$}

Carrot fibre powder can be made from carrot pomace, the by-product of carrot juice production. Carrot pomace is considered as one of the potential sources of health promoting substances such as carotenoids and fibre which can be added into food as ingredient. This study investigated the effects of incorporation of various carrot fibre powders on beef patties characteristics. Three types of carrot fibre powders (untreated, mechanically optimized, and concentrated) were used and compared to one type of citrus fibre. Patties without any fibre powder added was used as a control. The carrot fibre powders showed significant different physico-chemical and technofunctional properties compared to citrus fibre. Incorporation of the carrot fibre powders into beef patties increased the cooking yield and decreases shrinkage which was related to its water and fat retention capacity. Texture of beef patties was changed in a negative way, where decrease of hardness, cohesiveness, springiness, chewiness and gumminess were observed compared to control. No significant differences were observed among the carrot fibre powders on cooking characteristics and texture profile, but they differed when compared to citrus fibre. Yellowness of patties with untreated carrot fibre was significantly different for raw patties. For cooked patties, the difference in redness was observed for the untreated and mechanically treated carrot powders. Patties with $2.5 \%$ carrot fibre powder were accepted by consumers even though they still preferred patties with citrus fibre more.

As an example, Figure 17 shows the cooking yield (defined as the relative ratio between the cooked and raw weight) and the fat retention (defined as the relative ratio between the weight of the fat in a cooked samples and in a raw sample) of beef patties without (control) and with different kind of fibres at different concentrations. Figure 18 shows the results of the sensory analysis.

\footnotetext{
${ }^{2}$ Kusumaningrum, M.Y., M. Vollebregt, R. Verkerk, Effects of incorporation of various carrot fibre powders on beefpatties characteristics, In progress for publication, 2018.
} 

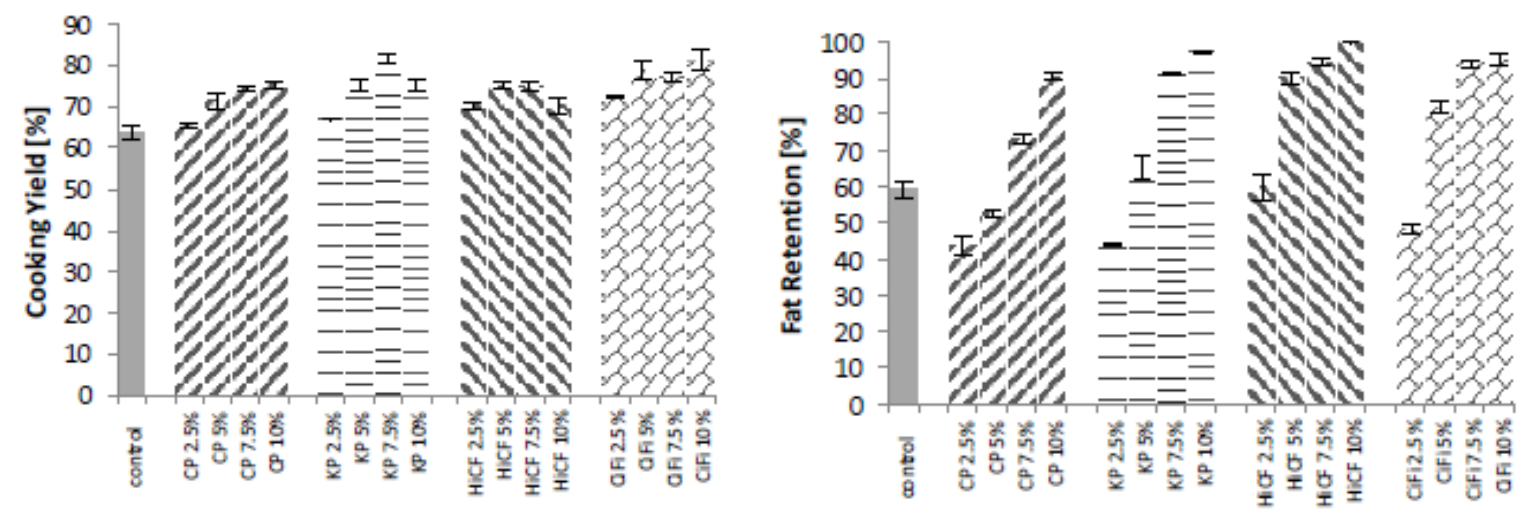

Figuur 17 Cooking yield (left) and fat retention (right) of beefpatties without (control) or with different kind of fibres added in different concentration. $C P=$ untreated carrot powder, $K P=$ mechanically treated carrot powder, $\mathrm{HiCF}=$ carrot powder with high fibre concentration, $\mathrm{CiF} i=$ citrus fibre.
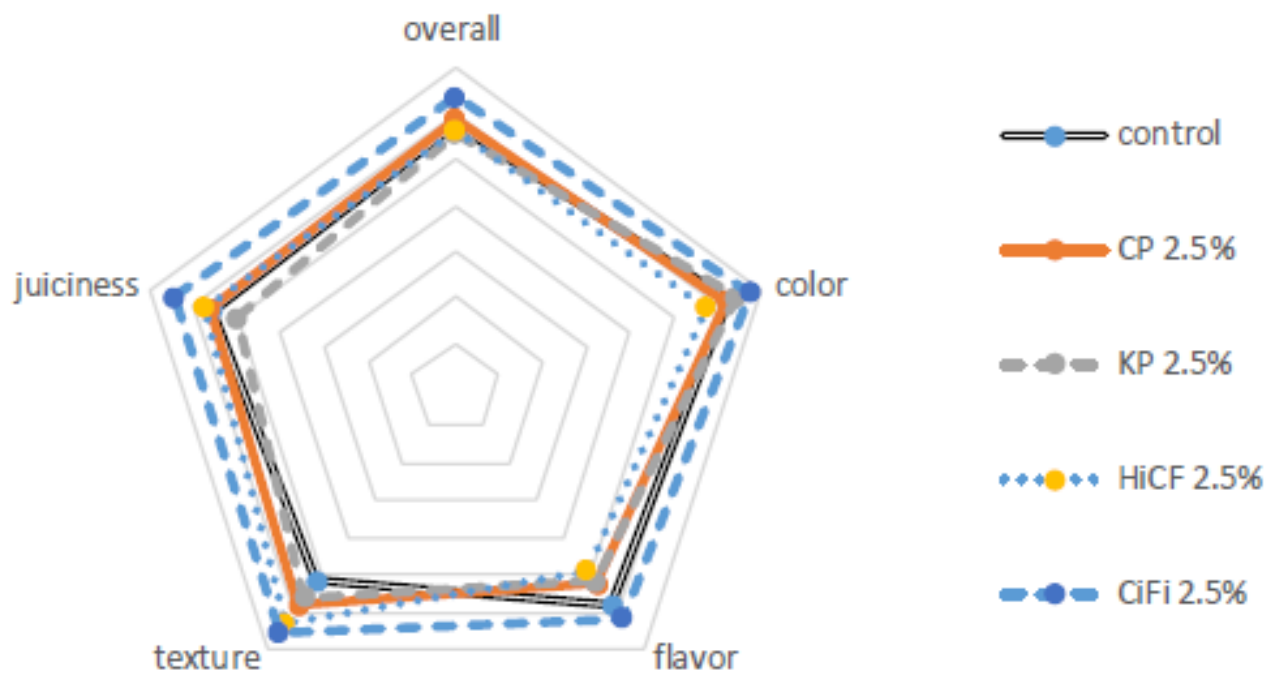

Figuur 18 Liking of sensory attributes of several beef patties incorporated by 2.5\% fibre powders. From centre to edge of spider web represents a bedonic scale from 1 (dislike extremely) to 9 (like extremely).

\subsection{Voorbeelden levensmiddelen met wortelvezels}

Ter illustratie van mogelijke toepassingen van wortelvezels in levensmiddelen en ter inspiratie voor mogelijke functionaliteit van vezels als ingrediënt is in de Innova database gezocht naar productintroductie met "carrot fiber" of "carrot fibre" als ingrediënt. Innova Market Insights, het bedrijf wat de database beheerd, registreert hierin productintroducties over de hele wereld en slaat onder meer informatie op over marktcategorie, land, positionering, smaken, ingrediënten en datum van introductie.

Eveneens is recent onderzoek in de wetenschappelijke literatuur op het gebied van vezels als additioneel of vervangend ingrediënt geïnventariseerd. Het betreft hier onderzoek naar technologische functionaliteit, niet naar gezondheid. 


\subsubsection{Marktintroducties met "carrot fibre" of "carrot fibre"}

De Innova database is begin 2016 onderzocht op marktintroducties van producten met wortelvezels gedurende de afgelopen 5 jaar. Onderstaande tabellen geven een samenvatting van de introducties op wereld of Europees niveau.

\begin{tabular}{|l|l|l|}
\hline & Wereldwijd & Europees \\
\hline Aantal introducties & 326 & 82 \\
\hline Positionering (\# introducties) & $\begin{array}{l}\text { Gemak (297), gezond (185), } \\
\text { keuze (gmo vrij, halal, kosher, } \\
\text { vegetarisch of veganistisch) } \\
(102)\end{array}$ & $\begin{array}{l}\text { Gemak (76), gezond (48), } \\
\text { ethisch (23) }\end{array}$ \\
\hline Ingrediënten & $\begin{array}{l}\text { Wortelvezel, zuren, water, } \\
\text { kruiden, suiker, zout, } \\
\text { knoflook, ui }\end{array}$ & $\begin{array}{l}\text { Wortelvezels, zuren, zout, } \\
\text { water, suiker, eieren, kruiden, } \\
\text { varken }\end{array}$ \\
\hline introducties) & $\begin{array}{l}\text { Groente (124); kip, vlees \& } \\
\text { vis (117); zaden en kruiden } \\
(62) ; \text { kruiden (56); zuivel } \\
\text { smaakstoffen (55) }\end{array}$ & $\begin{array}{l}\text { Kip, vlees \& vis (57); groente } \\
(20) ; \text { zaden en kruiden (16); } \\
\text { kruiden (14); fruit (12); zuivel } \\
\text { smaakstoffen (10) }\end{array}$ \\
\hline Product basis (\# introducties) & $\begin{array}{l}\text { Verscheidene, soja (16) en kip } \\
(10)\end{array}$ & $\begin{array}{l}\text { Verscheidene, kip (7) en } \\
\text { worst (5) }\end{array}$ \\
\hline Landen (\# introducties) & $\begin{array}{l}\text { USA (140), Canada (42), } \\
\text { Frankrijk (17) }\end{array}$ & $\begin{array}{l}\text { Frankrijk (17), Duitsland (11), } \\
\text { Nederland / Portugal / UK } \\
\text { (allen 8) }\end{array}$ \\
\hline
\end{tabular}

De Innova database kan automatisch diverse visualisaties van de producten genereren, bijvoorbeeld de verdeling van de introductie voor verschillende werelddelen / landen over de jaren of de verdeling over markt(sub)categorieën. Figuur 19 toont de verdeling van het aantal introducties voor marktsubcategorieën voor de wereldwijde en Europese introducties. In Figuur 20 staan een aantal typische voorbeeldproducten van de belangrijkste subcategorieën voor de Europese introducties. 


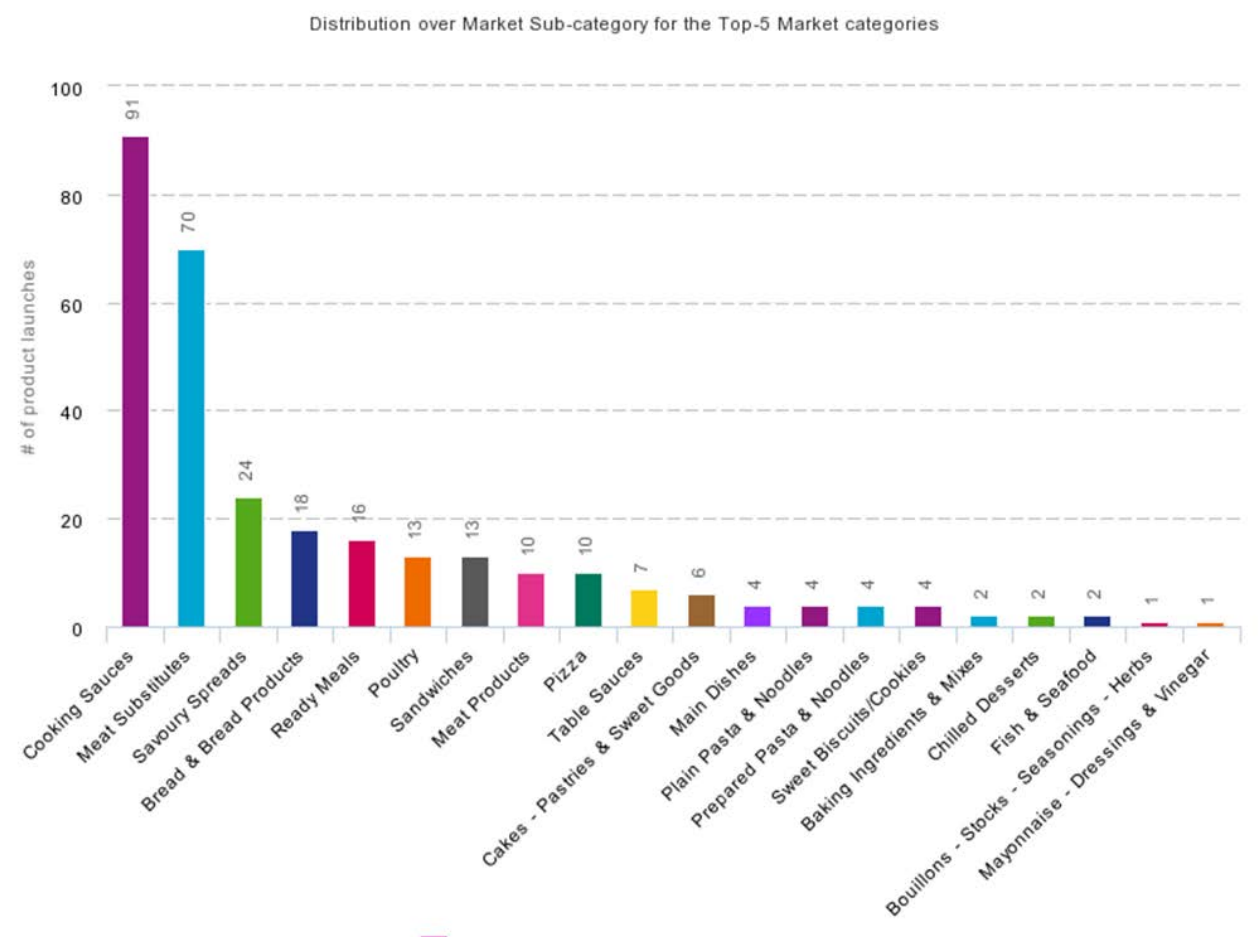

Market Sub-Category - 302

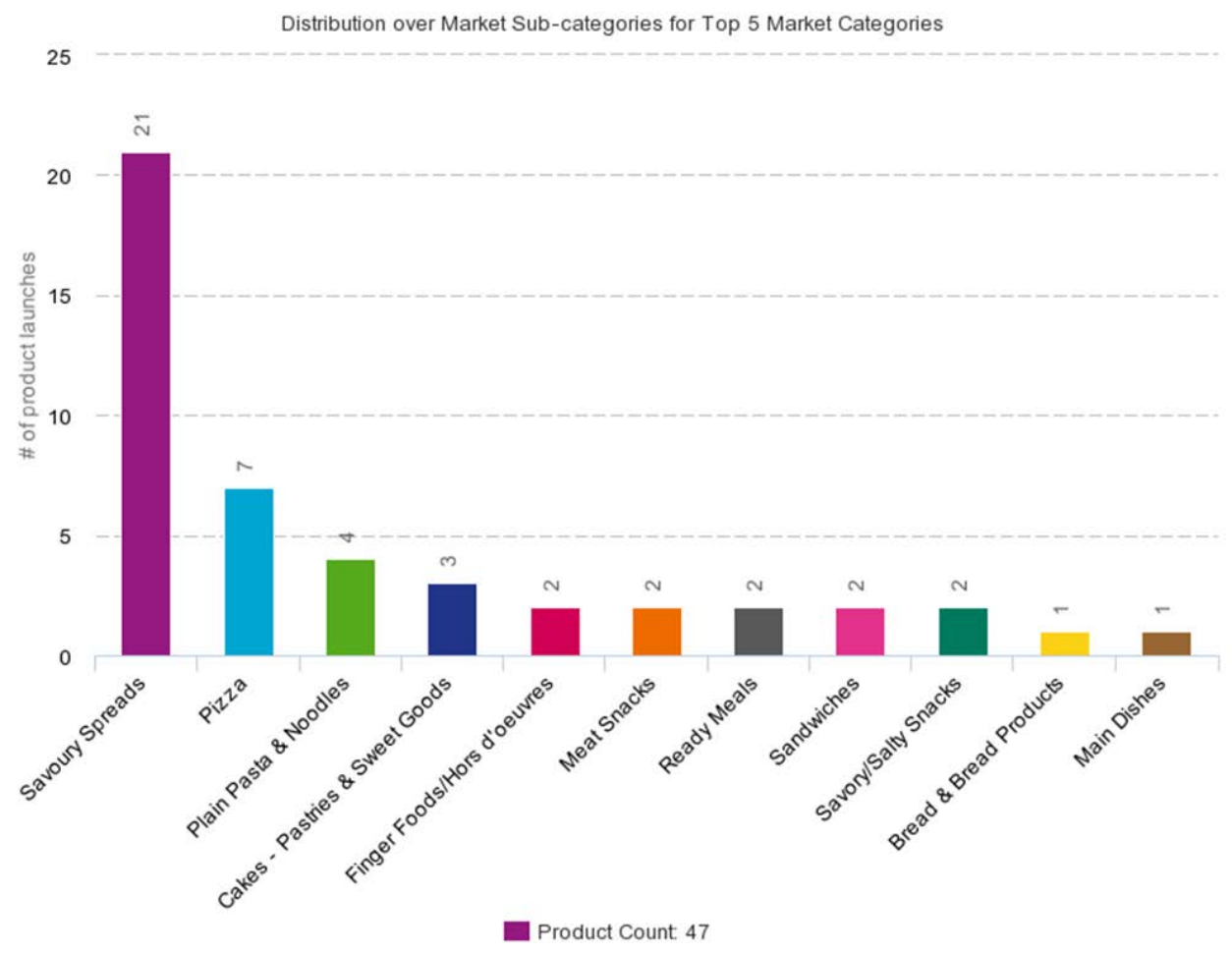

Figuur 19 Aantal introducties wereld wijd (boven) of in Europa (onder) van levensmiddelen met "carrot fibre" of "carrot fiber" als ingrediënt verdeeld over marktsubcategorieën. 
Savoury spreads (21)
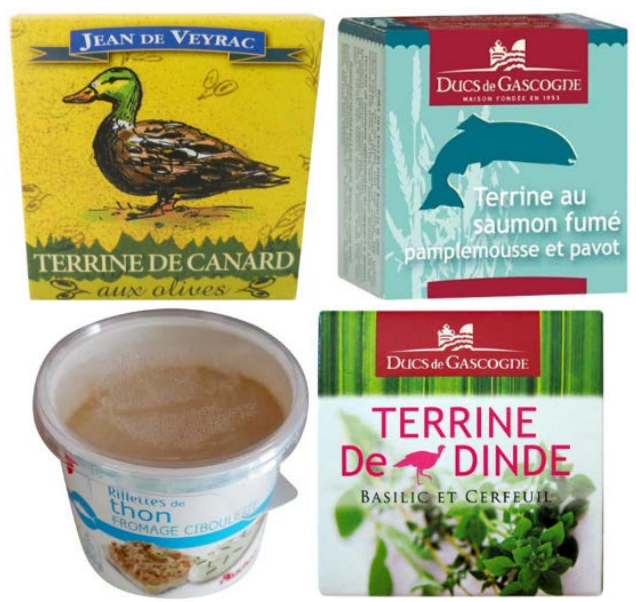

Plain pasta and noodles (4)

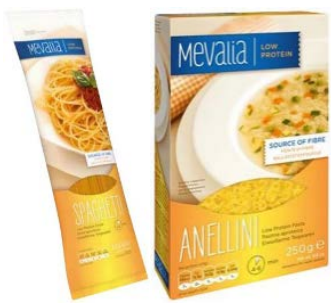

Pizza (7)

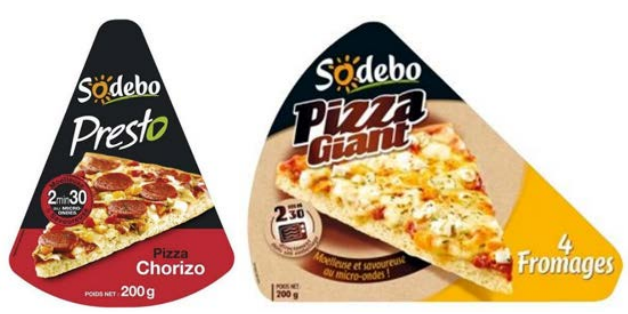

Cakes, pastries and sweet goods (3)

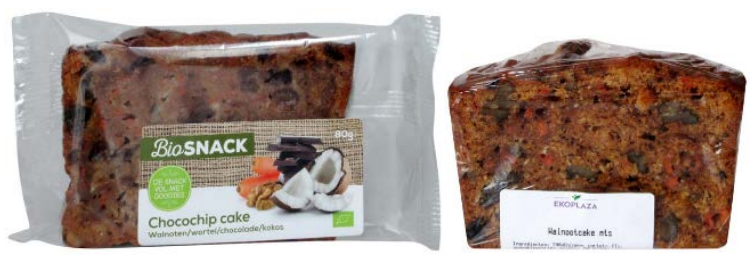

Figuur 20 Voorbeelden productintroducties in Europa in de afgelopen 5 jaar welke wortelvezels als ingrediënt bevatten.

\subsubsection{Onderzoek naar vezel als additioneel of vervangend ingrediënt}

In de wetenschappelijke literatuur zijn diverse artikelen te vinden over onderzoek aan toepassing van voedingsvezels uit groente en fruit in levensmiddelen gericht op functionaliteit van het ingrediënt en resulterende product eigenschappen. Onderstaande tabel geeft een overzicht van relevante artikelen met informatie over het product waarin de vezels zijn toegepast, het type vezel, eventuele motivaties of voordelen, opvallende zaken, type artikel en de referentie. 


\begin{tabular}{|c|c|c|c|c|c|}
\hline Product & Type of dietary fiber & Benefits + motivation & Remark & Type paper & Source \\
\hline \multicolumn{6}{|l|}{ DIFFERENT PRODUCTS } \\
\hline $\begin{array}{l}\text { Different products: bread, buns, } \\
\text { cake, pasta, noodles, biscuit, cookies; } \\
\text { meat products and meat analogues. } \\
\text { Ice cream, yoghurt, cheese, } \\
\text { beverages, milk shakes, instant } \\
\text { breakfasts, ice tea, juices, sports } \\
\text { drink, wine, powdered drink, } \\
\text { fermented milk products, } \\
\text { For liquid foods: soluble dietary fibre } \\
\text { is preferred; for rest both is used. }\end{array}$ & $\begin{array}{l}\text { Carrot pomace: } \\
\text { In buns } \\
\text { In wheat cookies }\end{array}$ & $\begin{array}{l}\text { Enriched in fibre and } \\
\text { vitamins } \\
1.5 \mathrm{x} \text { more water } \\
\text { absorption; } 1.5-2 \mathrm{x} \text { more } \\
\text { breaking strength }\end{array}$ & $\begin{array}{l}\text { Mentioned is: sources } \\
\text { of dietary fibre in food } \\
\text { processing by- } \\
\text { products; uses in food; } \\
\text { functional properties; } \\
\text { caloric content and } \\
\text { energy values; labelling } \\
\text { regulations } \\
\text { Low caloric content } \\
\text { make fibres suitable in } \\
\text { low caloric health } \\
\text { promoting products }\end{array}$ & $\begin{array}{l}\text { Review, focus } \\
\text { utilization of } \\
\text { by-products }\end{array}$ & Sharma, S.K., et al., 2016 \\
\hline $\begin{array}{l}\text { Oa bakery, yoghurt, meat products, } \\
\text { biscuits, cookies, pasta, noodles, } \\
\text { breakfast cereals }\end{array}$ & $\begin{array}{l}\text { Different types; carrot } \\
\text { fibre not mentioned }\end{array}$ & & $\begin{array}{l}\text { Very general, no } \\
\text { specific details on type } \\
\text { of } \\
\text { fibre/concentrations } \\
\text { used mentioned }\end{array}$ & Review & Dhingra, D., et al., 2012 \\
\hline \multicolumn{6}{|l|}{ MEAT } \\
\hline $\begin{array}{l}\text { Meat (general): mentioned are: } \\
\text { chicken nuggets, beef } \\
\text { sausages/burgers, buffalo meat } \\
\text { burgers; comminuted meat products; } \\
\text { ready to eat meat products (meat } \\
\text { balls); frankfurters }\end{array}$ & $\begin{array}{l}\text { General, very broad } \\
\text { range of fibres are } \\
\text { mentioned: vegetative } \\
\text { such as cereal pulse } \\
\text { flour, vegetable and } \\
\text { fruits pulp }\end{array}$ & & $\begin{array}{l}\text { Physicochemical and } \\
\text { sensory properties: As } \\
\text { binder, extender, filler, } \\
\text { fat replacer; } \\
\text { improving nutritional } \\
\text { components, pH, } \\
\text { WHC, emulsion } \\
\text { stability, shear press } \\
\text { value, sensory } \\
\text { characteristics (texture; } \\
\text { lubrication, } \\
\text { slipperiness, body and } \\
\text { mouth feel; } \\
\text { chewiness); increase } \\
\text { cooking yield; } \\
\text { freeze/thaw stability; } \\
\text { for health conscious } \\
\text { consumers }\end{array}$ & $\begin{array}{l}\text { General } \\
\text { review, very } \\
\text { broad (also on } \\
\text { health effects) }\end{array}$ & Talukder, S., 2015 \\
\hline
\end{tabular}




\begin{tabular}{|c|c|c|c|c|c|}
\hline Product & Type of dietary fiber & Benefits +motivation & Remark & Type paper & Source \\
\hline Pork sausages & $\begin{array}{l}\text { Carrot fibre (and potato } \\
\text { starch) }\end{array}$ & $\begin{array}{l}\text { Increased whitening; use } \\
\text { of starch and fibre had } \\
\text { more impact on textural } \\
\text { props than level of salt; } \\
\text { water binding capacity of } \\
\text { low salt sausages was } \\
\text { improved to same level as } \\
\text { high salts variants }\end{array}$ & $\begin{array}{l}\text { Reduction of salt in } \\
\text { combination with HP } \\
\text { treatment }\end{array}$ & & Grossi, A., et al., 2012 \\
\hline Pork sausages & $\begin{array}{l}\text { Carrot fibre (Fibre } 92 \% \\
\text { of which } 14 \% \text { soluble, } \\
78 \% \text { insoluble) }\end{array}$ & $\begin{array}{l}\text { HP treatment AND } \\
\text { inclusion of carrot fibre } \\
\text { improved emulsion } \\
\text { strength resulting in firm } \\
\text { sausages, and improved } \\
\text { sensory evaluation }\end{array}$ & $\begin{array}{l}\text { HP treatment AND } \\
\text { inclusion of carrot } \\
\text { fibre induces higher } \\
\text { order of network } \\
\text { organisation leading to } \\
\text { higher Young's } \\
\text { modulus (compressive } \\
\text { strength) and lower } \\
\text { Hencky strain } \\
\text { (deformation) }\end{array}$ & & Grossi, A., et al., 2011 \\
\hline Low fat beef burger & $\begin{array}{l}\text { Carrot fibre (Hydrobind } \\
\text { carrot fibre, } \\
\text { commercially bought!: } \\
92 \% \text { of which } 14 \% \\
\text { soluble, } 78 \% \text { insoluble ) } \\
2,4,6 \% \text { was added after } \\
\text { hydration with water } \\
\text { (using } 13 \text { times amount } \\
\text { of water) }\end{array}$ & $\begin{array}{l}\text { Up to } 2 \% \text { fibre could be } \\
\text { used to produce low-fat } \\
\text { hamburgers comparable } \\
\text { to regular burgers; carrot } \\
\text { fibre has higher fat } \\
\text { binding capacity than } \\
\text { lemon fibre, which might } \\
\text { restrict its use in low-fat } \\
\text { meat products }\end{array}$ & $\begin{array}{l}\text { Fat content reduced by } \\
\text { addition of water and } \\
\text { fibre }\end{array}$ & & Soncu, E.D., et al., 2015 \\
\hline Pork sausages & Carrot fibre & & & & Møller et al 2011 \\
\hline Fermented dry sausage & $\begin{array}{l}\text { Carrot fibre: } \\
\text { concentration } 3,6,9 \\
\text { and } 12 \% \\
\text { Made by: Dehydration } \\
\text { of fresh carrot; ground } \\
\text { to particle size } 0.355 \\
\mathrm{~mm}\end{array}$ & $\begin{array}{l}\text { Samples containing over } \\
3 \% \text { DF fermentation not } \\
\text { successful; also textural } \\
\text { parameters sign affected; } \\
\text { lipolytic process was only } \\
\text { affected at the } 2 \text { highest } \\
\text { concentrations }\end{array}$ & & & Eim et al 2008 \\
\hline
\end{tabular}




\begin{tabular}{|c|c|c|c|c|c|}
\hline \multicolumn{6}{|l|}{ BAKERY } \\
\hline $\begin{array}{l}\text { Bakery products } \ldots \ldots \ldots \ldots \ldots \ldots \\
\text { (Low fat) Meat products } \ldots \ldots \ldots \ldots\end{array}$ & $\begin{array}{l}\text {... with fruit fibres } \\
\ldots \text { with pectins, } \\
\text { celluloses, soy, wheat, } \\
\text { maize, rice, beet fibres }\end{array}$ & & $\begin{array}{l}\text { Not much details given } \\
\text { on the foods } \\
\text { Paragraph on fact that } \\
\text { by-products from } \\
\text { which high-added } \\
\text { values compounds can } \\
\text { be recovered (instead } \\
\text { of economic and } \\
\text { environmental } \\
\text { problem) }\end{array}$ & $\begin{array}{l}\text { Mainly on } \\
\text { vegetable } \\
\text { products as } \\
\text { source of } \\
\text { fibres }\end{array}$ & Rodriguez et al 2006 \\
\hline Wheat flour dough, wheat rolls & $\begin{array}{l}\text { Carrot pomace powder: } \\
1,3,5 \text {, and } 10 \% \\
\text { replacement of wheat } \\
\text { flour } \\
\text { Powder obtained after } \\
\text { juice pressing of carrots, } \\
\text { drying of pomace, } \\
\text { grinding and sieving } \\
(160-270 \mu \mathrm{m})\end{array}$ & $\begin{array}{l}\text { Farinographic } \\
\text { characteristics were } \\
\text { influenced (increased } \\
\text { water absorption, dough } \\
\text { development time and } \\
\text { stability etc) and } \\
\text { parameters of final } \\
\text { product (decreased loaf } \\
\text { volume and cambering). } \\
\text { Sensory evaluation of rolls } \\
\text { were most acceptable }\end{array}$ & & & Kohajdova et al 2012 \\
\hline Biscuits & Wheat and apple fiber & & & & Laguna et al 2011 \\
\hline \multicolumn{6}{|l|}{ JUICES AND SO } \\
\hline Vegetable juices & Carrot puree & & & & Moritaka, 2012 \\
\hline \multicolumn{6}{|l|}{ DIARY } \\
\hline Yoghurt gels & Carrot wall particles & & & & Puvanenthiran et al 2014 \\
\hline Yoghurt & $\begin{array}{l}\text { Different vegetable } \\
\text { pomaces }\end{array}$ & & & & Najgebauer-Lejko et al 2015 \\
\hline \multicolumn{6}{|l|}{ PASTA } \\
\hline Pasta & $\begin{array}{l}\text { Carrot puree: max. } \\
420 / \mathrm{kg} \text { pasta } \\
\text { Homogenized carrot } \\
\text { puree from fresh carrots }\end{array}$ & $\begin{array}{l}\text { High yellowness; lower } \\
\text { cooking loss, swelling } \\
\text { index, and other texture } \\
\text { values than the control. } \\
\text { Carrot containing pasta } \\
\text { was comparable to the } \\
\text { control! (other vegetable } \\
\text { purees not: beetroot; } \\
\text { spinach, tomato) }\end{array}$ & & & Rekha, 2013 \\
\hline
\end{tabular}




\section{Referenties}

Dhingra, D., M. Michael, H. Rajput, R.T. Patil, Dietary fibre in foods: a review, Journal of Food Science and Technology, 49(3), 255-266, 2012

Eim, V.S., S. Simal, C. Rosselló, A. Femenia, Effects of addition of carrot fibre dietary fibre on the ripening process of a dry fermented sausage (sobrassada), Meat Science, 80(2), 173-182, 2008

Grossi, A., J. Soltoft-Jense, J.C. Knudsen, M. Christensen, V. Orlien, Meat Science, 89(2), 195-201, 2011

Grossi, A., J. Soltoft-Jensen, J.C. Knudsen, M. Christensen, V. Orlien, Reduction of salt in pork sausages by the addition of carrot fibre or potato starch and high pressure treatment, Meat Science, 92(4), 481-489, 2012

Kohajdova, Z., J. Karovicova, M. Jurasova, Influence of carrot pomace powder on the rheological characteristics of wheat flour dough and on wheat rolls quality, Acta Sci. Pol., Technol. Aliment., 11(4), 381387,2012

Laguna, L., A. Salvador, T. Sanz, S.M. Fiszman, Performance of a resistant starch rich ingredient in the baking and eating quality of short-dough biscuits, LWT-Food Science and Technology, 44, 737-746, 2011

Moller, S.M., A. Grossi, M. Christensen, V. Orlien, J. Soltoft-Jensen, I.K. Stradt, A.K. Thybo, H.C. Bertram, Water properties and structure of pork sausages as affected by high-pressure processing and addition of carrot fibre, Meat Science, 87 (4), 387-393, 2011

Moritaka, H., S. Sawamura, M. Kobayashi, M. Kitade, K. Nagata, Relation between the rheological properties and the swallowing characteristics of vegetable juices fortified with carrot puree, Bioscience, Biotechnology, and Biochemistry, 76(3), 429-435, 2012

Najgebauer-Lejko, D., M. Tabaszewska, T. Grega, The effect of addition of selected vegetables on the microbiological, textural and flavour profile properties of yoghurts, Acta Sci. Pol., Technol. Aliment., 14(1), 45-53, 2015

Puvanenthiran, A., C. Stevovitch-Rykner, T.H. McCann, L. day, Synergistic effect of milk solids and carrot cell wall particles on the rheology and texture of yoghurt gels, Food Research International, 62, 701-708, 2014 Rekha, M.N., A.S. Chauhan, P. Prabhasankar, R.S. Ramteke, G. Venkateswara Rao, CyTA - Journal of Food, 11(2), 142-149, 2013

Rodriguez, R., A. Jimenez, J. Fernandez-Bolanos, R. Guillen, A. Heredia, Dietary fibre from vegetable products as source of functional ingredients, Trends in Food Science \& Tecbnology, 17(1), 3-15, 2006

Sharma, S.K., S. Bansal, M. Mangal, A.K. Dixit, R.K. Gupta, A.K. Mangal, Utilization of food processing by-products as dietary, functional, and novel fibre: a review, Critical Reviews in Food Science and Nutrition 56(10), 1647-1661, 2016

Soncu, E.D., N. Kolsarici, N. Cicek, G.S. Ozturk, I.T. Akoglu, Y.K. Arici, The comparative effect of carrot and lemon fibre as a fat replacer on physico-chemical, textural, and organoleptic quality of low-fat beef hamburger, Korean Journal for Food Science of Animal Resources, 35(3), 370-381, 2015

Talukder, S., effect of dietary fiber on properties and acceptance of meat products: a review, Critical Reviews in Food Science and Nutrition, 55(7), 1005-1011, 2015 